\title{
a population on the move
}

A study of the socio-economic manifestations of internal displacement in relation to Kabul, Afghanistan 
This report was prepared with financial assistance from the Commission of the European Communities. The views expressed herein are those of the beneficiary and therefore in no way reflect the official opinion of the Commission. 


\section{Contents}

1. Introduction

2. Methodology

3. The Context

3.1 The Political and Military Context 5

3.2 The Nature of the Economy

3.2.1 The Macro Economy

3.2.2 The Intermediate Economy 10

3.2.3 The Micro Economy: Coping Strategies at the Level of the Family 11

$\begin{array}{ll}\text { 4. The Situation of the Displaced } & 17\end{array}$

4.1 The Nature of the Displacement $\quad 17$

$\begin{array}{ll}4.2 \text { Provision for the Displaced } & 20\end{array}$

5. Appendix 1 : Summary of Relief Provision by agency (December 1997) 23

Appendix 2: Interviews undertaken in Mohammed Agha 25

Appendix 3: List of those interviewed $\quad 29$

6. Maps of the districts of Kabul and surrounding area

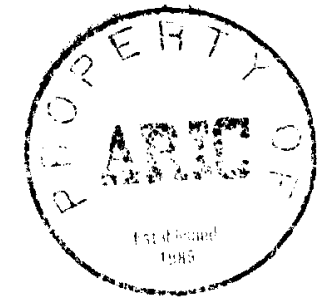




\section{Acknowledgements}

This study benefited enormously from the logistical support and cooperation extended by UNHCR, ICRC and UNOCHA. The time given by those interviewed, who were clearly working under significant pressure, is also very much appreciated.

Peter Marsden

Co-ordinator

British Agencies Afghanistan Group 


\section{Introduction}

The purpose of this study was to look at the nature of population displacement within the city of Kabul and to consider the socio-economic situation of those displaced. To this end, it was also necessary to consider the nature of the wider economy in a situation in which a large-scale relief programme was in operation, which had been augmented in response to winter conditions. 


\section{Methodology}

Information was collected primarily from humanitarian agencies, a number of which had conducted studies of the socio-economic situation or kept ongoing records which provided valuable data. The recorded information was supplemented by anecdotal information or by personal observations based on knowledge and experience of the local situation. Previous studies undertaken by the researcher, including one in July 1995, provided a useful baseline for the information obtained.

It had been hoped that it would be possible to interview individual families in order to achieve a greater qualitative understanding of the situation. However, it was felt, on the basis of consultation with a number of agencies, that this could put the families concerned at risk. It was concluded that the quality of information already available from the agencies was largely sufficient and that the additional information which could be obtained from interviews with families would not justify the potential risks involved, given that it would be necessary to undertake a reasonable number of interviews in order to achieve a balanced picture. However, interviews were conducted with three families in the rural district of Mohammed Agha, to the south of Kabul, to ascertain the coping strategies of those who had returned to the villages from Pakistan or Kabul. 


\section{The Context}

\subsection{The Political and Military Context}

The Soviet-backed Government, which ruled from 1978-1992, with Kabul as its capital, held the major urban centres and a number of minor ones. It had only minimal control or influence over the rural areas, which were in the hands of the Mujahidin parties or fragmented amongst local tribal or village structures or military commanders.

The Soviet-backed Government was replaced in 1992 by a Government made up principally of the Peshawar-based Mujahidin parties which had played a key role in the resistance movement. This Government, which was in power until the Taliban took Kabul in September 1996, failed to achieve internal unity and the capital was affected by fierce internal fighting, and by rocketing and shelling from outside, for much of the period. Intense rocketing in January 1994 resulted in large-scale population movements to Jalalabad, where huge camps were established, and to Pakistan. Tensions with the northern leader, Dostam, inhibited access for trade over the Salang Pass to Central Asia. Periodic blockades also restricted the flow of goods to and from Kabul to Pakistan on both the Jalalabad and Kandahar roads.

The arrival of the Taliban in Kabul opened up the roads to Pakistan but determined attempts to take the fertile Shomali Valley to the north of Kabul, and equally determined resistance by the northern forces, brought trade to a virtual standstill over the Salang Pass and also affected agricultural production in the Shomali Valley and the marketing of produce in Kabul.

Two abortive efforts by the Taliban to take Mazar, in May and September 1997, have both benefited from and generated growing instability in parts of the northern provinces. This instability has provoked movements of population to the south and also resulted in the closure, until recently, of the border with Uzbekistan, thus setting the final seal on trade with Central Asia over this route. 


\subsection{The Nature of the Economy}

\subsubsection{The Macro Economy}

Kabul's economic role has, historically, been based on a number of key factors:

- its position astride the major communications route for trade between Central Asia and the North-West Frontier Province of Pakistan.

- $\quad$ linked with above, its position as a business and financial centre.

- its position as a seat of government and employer of government servants.

- its position as a bazaar centre for the surrounding agricultural area.

Kabul's position as a trading entrepot has been severely affected by the effective closure of the northern route over the Salang Pass, by the existence of the front line between the Taliban and opposition forces and, previously, between the Rabbani administration and Dostam's forces. The physical damage to the Salang Pass has also hampered, if not completely prevented, its use for motorised transport. The ongoing insecurity in the north has served as a further disincentive to traders to try to find a way around the front line and, as indicated above, the closure of the Uzbek border has represented a further block to trade. It is, nonetheless likely that some trade is making its way in from the north, albeit on a small scale.

As a consequence of the severe constraints on the northern route, the western route from Turkmenistan, through Herat, Kandahar and the border town of Chaman to Pakistan, has taken on a much greater significance. It would appear that most trade is now passing along this route and that very little is transiting Kabul.

The Chaman border is also being used for the export of timber logged in Paktia and, possibly, Kunar. The timber from Paktia is thought to be making its way to Kandahar and Chaman via Ghazni, thus bypassing Kabul. Timber from Kunar could cross directly into North-West Frontier Province or be transported through Chaman. For the latter route, it could travel through Kabul or take a more direct route, on poorer roads, which also bypasses Kabul. To the extent that wood from Kunar is passing through Kabul, it may be taxed. However, this is highly speculative. What is clear is that a very considerable quantity of timber is passing through Kandahar and Chaman.

It is also likely that the benefits of the black economy, manifested particularly in the heroin trade and smuggling, are not reaching Kabul on any scale. The two centres of poppy growing, Helmand and Nangarhar, have outlets to Chaman and North-West Frontier Province respectively. The Helmand production can also travel north to Herat and Turkmenistan and some of the Nangarhar production may find its way through Badakshan and Tajikistan. Although it has been rumoured that opium is being flown from Kabul to Kunduz, Kabul is clearly not a major transit centre.

With Kandahar acting as the primary entrepot for both transit trade from Central Asia, for timber exports and for a substantial part of the poppy and heroin trade, it has inevitably taken over Kabul's role as the financial centre of Afghanistan and currency rates are now set there.

Jalalabad is also an important financial centre and has an economy which is dramatically more 
buoyant than that of Kabul. While its agricultural fertility and opium production are important contributory factors, its role as an entrepot for consumer goods flown in on Ariana Afghan Airlines from Dubai and then smuggled into Pakistan is economically significant. The use of the border town of Torkham for the smuggling, into Pakistan, of goods which have been brought in from Karachi, duty free, may also bring income to Jalalabad. However, the linkages between Pushtun traders on both sides of the Pakistan border make it difficult to indicate, with any precision, to what extent the benefits of smuggling accrue to Afghanistan or to Pakistan. However, it is unlikely that the largely Tajik and Hazara populations of Kabul will gain from the smuggling trade.

With little trading money coming into Kabul and, therefore, extremely limited purchasing power, there is, on the face of it, little incentive for businessmen to invest in the city. The industrial sector has virtually vanished and it was never strong. Much of what used to exist was artificially propped up by the Soviet-backed economy. The Kabul economy has traditionally drawn more on small-scale workshops and home-based production, but this element is also being eroded as market outlets reduce. Empty shops are visible in abundance and the shops that remain are said to have an extremely limited turnover. Some observers felt that there were the beginnings of renewed investment and the construction of a few shopping centres to the south of Khair Khana may have been part of this. Others commented that there was significant capital flight to Pakistan, Dubai and the USA. Whatever the actual level of investment, all the indicators suggested an economy in crisis.

This was particularly evident from changes in street trading, which has always represented an important aspect of the Kabul economy. From visual observation, this seems to have increased in scale relative to the previous visit of the researcher in 1995, but much of it relates to the sale of well-used personal possessions and to basic foodstuffs. Here, there was a stark contrast with Jalalabad, where many new items were for sale.

Kabul's role as the seat of government has also undergone a marked transformation. It should be noted, in this context, that the state bureaucracy has never exercised much control beyond the urban areas. The economy of Afghanistan has been traditionally based on subsistence agriculture and the state has provided little by way of services and infrastructure to the countryside. Further, the rural population has consciously sought to keep the state at a distance. It was only with Daoud's premiership from 1953-63 that the state machinery started to expand, even within the urban areas, and this process continued during the $1960 \mathrm{~s}, 70 \mathrm{~s}$ and $80 \mathrm{~s}$, facilitated by Soviet investment.

Major infrastructural improvements, such as the construction of highways linking the principal urban centres, were the direct result of foreign assistance. The People's Democratic Party of Afghanistan (PDPA) regime of 1978-1992, in its early stage prior to the Soviet invasion, attempted to extend the state apparatus into the rural areas but failed. It did, however, provide a reasonable level of health care and school-based education within the urban areas and also offered employment opportunities to both women and men within the state bureaucracy and in health and education services, continuing a trend started by Daoud.

When the Mujahidin took power in April 1992, the initial anarchy which prevailed paralysed the functioning of government and salary payments became unreliable. Civil servants also ceased to have access to the supplementary package of food items and fuel provided, along with the salary, by the Soviet-backed Government. At this stage, many Government employees found themselves having to supplement their incomes through involvement in trading activities. A process of selling off assets and borrowing money also began. Many decided to leave for Pakistan, India or Iran. This exodus of professionals was yet another wave, following on the purges of the PDPA Government in 19789, which sent many into exile, and the large-scale move of educated people to Europe and North 
America in response to the war conditions of the early 1980s. The heavy rocketing of Kabul in August 1992 sent yet more professionals to Mazar, and the even greater onslaught on Kabul in January 1994 provoked a dramatic flight to Jalalabad and Pakistan of those with the means to escape. Thus, by the time the Taliban took Kabul in September 1996, the civil administration was much depleted. The arrival of the Taliban sent yet more to Pakistan and Iran, or to the north of Afghanistan, in response to the non-payment or delayed payment of salaries, reducing sources of supplementary or alternative employment, declining assets, the selective dismissal of Government staff (particularly women) and the restrictions imposed on dress and behaviour. The climate of fear was a further contributory factor.

The position has now been reached where the state bureaucracy gives very little employment, perhaps to no more then 3,000 people, providing for approximately $2 \%$ of families. Further, the salary levels are not sufficient to ensure basic needs and have to be supplemented by other income sources. Payment is also irregular. Government employment, therefore, makes very little contribution to the economy and generates a minimal level of purchasing power.

The economy has been further weakened by a disastrous management of the money supply. The Mujahidin administrations of 1992-96 created spiralling inflation by printing money and there are indications that the Taliban administration may be doing the same. Further chaos was created at one point by Dostam printing his own money for the northern region and by the Taliban refusing to permit certain denominations of notes printed by the opposition to be used in the market.

Taking account of all these factors, it could legitimately be argued that the economy of Kabul is barely viable. For the broad mass of the population, there are very few options to generate an income and there is a heavy dependence on a selling of assets, borrowing and on relief distributions. There is, therefore, very little that humanitarian agencies can do to strengthen the economy beyond the creation of additional purchasing power through the operations of agency programmes and the personal expenditure of agency staff. It may, thus, not be realistic to aim at sustainability under present economic conditions. Agencies may have some minimal impact through income-generation or training programmes and these may have the added benefit of providing dignity to what is, essentially, a large welfare programme but, beyond this, the potential to make a difference is extremely limited.

Having said that, it is not acceptable for external agencies to maintain such a welfare system without an exit strategy. At the present time the support provided by the agencies is clearly essential, with much of the population nearing destitution, but agencies need to look for opportunities to hand over responsibility for basic services to the governmental administration. This process may take some time but a handover has to be the ultimate objective. How this is done without building the capacity of the present administration is a dilemma which agencies and donors have to grapple with.

While the Kabul economy may have minimal viability, the population of Kabul have strategies open to them to draw on external sources of income. Some will have land in the surrounding area. Many will have family members working in Iran and Pakistan. The pattern very much evident in the rural areas of sending sons to work in the neighbouring countries is, thus, also present in Kabul. While earlier studies undertaken by the researcher indicate that the benefit of this is more that there are fewer mouths to feed than that any significant income comes in, in the form of remittances, such economic migration is an important element in economic survival. It must be emphasised, however, that the alternative strategies, whether working on the land or opting for economic migration, offer only a marginal level of survival. 
In looking at options for humanitarian agencies to strengthen these external sources, there is, of course, nothing that the agencies can do to improve the economies of Pakistan and Iran. The only serious option open to humanitarian agencies, in terms of medium to long-term sustainability, is to improve the agricultural economy of the surrounding region, namely the Shomali Valley and Wardak, Logar and Kabul Provinces. Such improvements could provide escape valves for an urban economy under strain. Already, much is being done in Logar to support refugee return and agricultural reconstruction. The case studies in Appendix 2 are illustrative of this. Wardak has benefited from years of agricultural assistance but more remains to be done. The Shomali Valley has similarly benefited from previous assistance but now faces a particular crisis, following the partial destruction by a rocket in May 1997 of a syphon which ensures the irrigation of a huge area. ICRC is currently planning remedial and repair work to the syphon and the related irrigation systems.

This emphasis on agricultural production as a mechanism for strengthening the Kabul economy is consistent with the fact that the present population of Kabul is predominantly rural in character and in its skills. It, therefore, has the capacity to adapt to both urban and rural environments, albeit as unskilled labourers in relation to the urban environment.

\subsubsection{The Intermediate Economy}

This is defined as the element in the economy which provides services and infrastructure to the population.

There exists a basic structure of governmental and local authority administration, manifested particularly in the Ministry of Public Health, Ministry of Water and Power, Ministry of Public Works, Ministry of Education, Central Authority for Water Supply and the Kabul Municipality. In addition, there are Ministries and Departments which agencies need to relate to which have primarily a controlling function, either in relation to external agencies or to the population. These are the Ministry of Foreign Affairs, the Ministry of Planning, the Ministry of Justice and the Department for the Promotion of Virtue and the Prevention of Vice.

These Ministries and Departments are not considered to have the capacity, at the present time, to ensure a reasonably adequate level of basic services to the population. Humanitarian agencies and donors have, therefore, opted to supplement these services so as to ensure an adequate health coverage, access to clean water, the removal of human and other waste and a minimal level of nutrition. As indicated above, in spite of the combined resources of the Taliban administration and the humanitarian agencies, the population remains in a situation of encroaching destitution.

There is scope to both strengthen the capacity of government and to expand the programmes of the agencies, particularly those tackling nutrition needs, but progress is undermined by a complex relationship between the authorities and the agencies. It is beyond the scope of this report to consider the nature of that relationship except to note that it would be easier to resolve if the severity of need were not so acute.

In looking in detail at the provision of services, we can observe that external agencies, together with the Ministry of Public Health, are ensuring a level of hospital-based, clinic-based and outreach services. These include vaccination, mother and child health and midwifery services. There are also specialist hospital-based services for the control of diarrhoeal diseases, acute respiratory infection, TB, malaria and leishmaniasis. There is a particular focus on leishmaniasis control. The incidence of leishmaniasis has increased from 14,000 cases in 1995 to 300,000 at present (WHO figures). In addition, agencies tackle severe nutrition problems through a network of therapeutic and supplementary feeding centres. 
The health service would appear to be reasonably comprehensive and professionally managed. However, it was beyond the brief of this study to assess its adequacy relative to need, particularly when the relationship between nutrition and health is so finely balanced under the present economic conditions.

A number of humanitarian agencies work together to enhance the income and nutrition levels of a significant proportion of the population. Approximately one third of the population are benefiting from a combination of the WFP/ACTED subsidised bread programme, various programmes targeted at widow-headed and women-headed households and from food-for-work, income-generation and institutional feeding programmes. Many agencies are endeavouring to maintain the dignity of the population as far as possible, through the creation of work opportunities.

In addition, agencies are working with the Municipality to provide access to clean water and to clear human and other waste.

There are also programmes in support of house building, in which window frames, doors and roof beams are provided to returning refugees and IDPs.

All these programmes could, in broad terms, be defined as essential to sustain life. However, it has proved difficult to ensure equality of access to all services, to both women and men, and to also ensure that action is not taken which might undermine equality of access to a full range of public services in the future. This is not easy in that certain actions carry the risk of undermining future equality even if they will not automatically lead to it. However, the agencies cannot operate in a vacuum. Demands are being made of them which require a response. Agencies can choose to adopt a minimal risk position by opting not to go down any path which carries a high degree of risk (e.g. that future female access to health care may be reduced) or they can seek to negotiate safeguards. With a range of positions and attitudes being taken within both the Taliban authorities and the humanitarian aid community, including both providers and donors, this is necessarily a complex and unpredictable process. It is, therefore, one in which there are no guarantees.

\subsubsection{The Micro Economy: Coping Strategies at the level of the Family}

Comparisons with the visit to Kabul undertaken by the researcher in 1995 indicate a visible change in the economic situation of the population, manifested in the existence of begging as an economic activity. However, it is not just that begging is present. It is actually widespread, evident in all areas of town, and intensive, so that, in any given area, large numbers of children will cluster to ask for money and, in addition, women will be found begging in significant numbers.

The level of poverty is also visible in that many shops have closed and, as indicated above, there are far more stalls in evidence. Further, a high proportion of these stalls are selling household possessions. Oxfam reported that, from its monitoring of the second-hand market, there had been a marked trend, over the previous few years, for assets of ever declining value to be sold. At the time of the study, there were few items of any value for sale and most stalls were selling goods which were well-used and of virtually no value, e.g. a bent spoon, half a shalwar kamis.

There are very few opportunities for employment. WFP commented that, perhaps, $20 \%$ might find work and this would be in either labouring or on the food-for work programmes organised by humanitarian agencies. 
For many people, the selling of assets and borrowing represent important sources of income. Some are able to borrow against future agricultural production of their land. Others have no hope of being able to repay. This creates a disincentive to find work, even on food for work programmes, because creditors will be quick to demand repayment if any income is secured. Much of the borrowing is from relatives and neighbours. Relatives and neighbours are also important sources of charitable giving. The poorest families will thus be given food, for the most part, by those in the immediate vicinity.

Families also facilitate their survival by maximising their options. Many families will be split between Kabul and the outlying rural areas, keeping a base in both areas in case fighting erupts in either of the two, or to take advantage of relative economic benefits. Some, as mentioned above, will have family members working in Pakistan. Families, or parts of families, are frequently on the move as the relative advantages or disadvantages of staying in one place or another changes over time.

Potentially, the agricultural areas offer greater economic security than do the urban areas and also lower living costs, manifested in the greater availability of fuel sources, absence of rent and greater extended family support. However, the services and welfare provision on offer in Kabul represent something of a magnet, however small.

Information was collected on the strategies adopted by women and children in their efforts to survive. The following were noted:

- Both women and children would search for anything burnable, including animal dung.

- Older children would work in a bakery, push a cart to transport the goods of others or sell cigarettes.

- Women would wash clothes

- Women would periodically help others with a major spring clean or undertake regular cleaning.

- Children would constantly ask foreigners for bits of work, e.g. shoe polishing, car cleaning.

- Children weave carpets. This was said to be a significant area of economic activity.

- Women and children beg.

- Children pick up plastic bags to sell.

- Women have some meals cooked by neighbours.

- Women and children benefit from relief distributions and from subsidised bread.

- Women borrow from relatives, neighbours and shopkeepers.

- Women make paper bags, envelopes, brooms and baskets.

- Women undertake embroidery and tailoring.

- Women cook for others. 
- Women work as private teachers or in the health sector.

- Women spin wool.

- Women clean raisins and break almonds on a seasonal basis.

The following sources of income for women were noted to have reduced or been lost:

- tailoring and embroidery

- teaching

- telephone operating

- typing

- administration

- government employment

- hospital employment.

The primary sources of income for men at the time of the study were said to be:

- labouring

- carpentry

- pushing handcarts, to transport the goods of others.

A number of studies have been undertaken which provide indicators of hardship. One was an assessment of the household food security and nutritional situation in Kabul undertaken by ICRC in December 1996, based, in part, on a sample survey of 300 families in one district (District 7) in southern Kabul. Another was a Socio-Economic Household Survey undertaken by Action Contre La Faim, also in December 1996. This was based on interviews with 1,200 families selected at random from clusters throughout the city. Comparisons between these major studies, and with information provided by other agencies, are given below.

\section{Sharing of accommodation}

The ICRC study found that, on average, 2 families were sharing the same house or compound. ACF found an average of two to three. It also concluded that $53 \%$ of families were sharing with at least one other family.

\section{Family composition}

Within the sample population for the ICRC study, $82 \%$ of the families were headed by a man, $12 \%$ by a widow, $5 \%$ by a woman whose husband was elsewhere and $2 \%$ by a disabled person. The 
average family size was 7 members. In $15 \%$ of the families, one or more members had left Kabul during the 3 months preceding the survey.

The ACF survey found that $13 \%$ of families were headed by widows.

\section{Displacement}

Of the ICRC sample, only 1 in 10 of the families had never left their house during the conflict and almost 6 out of 10 had moved three to four times before arriving. It should be noted, however, that the District selected was in one of the areas affected by internal fighting, and by rocketing and shelling from outside the city.

The ACF study concluded that more than two thirds of families had been affected by displacement within the previous year. It noted that $64 \%$ were internally displaced and that $9 \%$ were returnees. Of these two groups combined, $58 \%$ had moved within Kabul and $42 \%$ had come to the capital from other parts of Afghanistan, particularly the rural areas, or were returnees. A total of $91 \%$ had moved because of the war.

CARE, through a sample survey of 934 widows assisted through its relief distribution programme, found that $80 \%$ of these had been displaced from rural areas.

\section{Employment}

Of the ICRC sample, there was less than one adult working member per family, on average, with almost 4 families out of 10 having no-one working at the time of the survey. This is broadly consistent with the $20 \%$ employment rate given above, taking account of all men and women above 15 years of age being potential members of the workforce.

However, the ICRC sample found that $20 \%$ were working for the Government. If extrapolated to the wider population, this would suggest that around 20,000 people were employed within the Government administration. This does not square with the estimate of 3,000 which I was given verbally but it is possible that the real figure is somewhere in between, taking on board the continuing exodus of civil servants and the large-scale dismissals undertaken by the Taliban in their efforts to prune the bureaucracy and weed out unacceptable members.

The ICRC sample found that, of the remaining $80 \%, 50 \%$ were engaged as daily labourers, $16 \%$ were shop-keepers, buyers- resellers or petty traders, $7 \%$ were skilled workers (carpenters, masons, stove makers etc.) and $4 \%$ were farmers (part of the area was rural).

While noting extremely wide variations in wage levels, the very intermittent nature of daily labouring and the irregular payment of government salaries, ICRC computed the dollar equivalent of average monthly earnings for individual workers within the various groups, as follows: government employees (when paid): $\$ 5$; daily workers: $\$ 7.50$; traders: $\$ 7.30$ and skilled workers: $\$ 5.60$. The apparent financial advantage to be gained from being a daily labourer derived from the much wider range between the lowest paid $(\$ 1.10)$ to the highest $(\$ 26)$.

The ACF study recorded that $11 \%$ of families had no-one in employment and that $68 \%$ had one person in employment. The remaining $21 \%$ had two or more people working.

CARE's study indicated that, because only $15 \%$ of its sample had been in receipt of some kind of 
education, there were limits to the types of occupation which the widows could undertake. Their potential was also said to be constrained by the fact that any goods the women could produce were unlikely to sell in the bazaar at an adequate price - second-hand or imported goods were much cheaper.

The study also noted that, of 74 women who had worked in the past, 45 had worked for the government as teachers, telephone workers, typists and health sector staff. The others had derived an income through tailoring or embroidery.

It found that 182 women within the sample group were now engaged in economic activity, through washing clothes, cleaning, tailoring, wool spinning, picking vegetables, knitting, collecting leaves and bushes for fuel, cleaning raisins, breaking almonds, making envelopes and paper bags, begging and as private teachers. The major sources of income, in roughly equal proportions, were direct engagement in economic activity, sending children to find work or collect fuel and help from relatives and neighbours. Begging was said to generate $6 \%$ of average income.

\section{The involvement of children in economic activity}

Of the ICRC sample, $71 \%$ of families had children engaged in economic activity, including petty trading and transportation and the collection of wood, dead leaves and garbage as fuel.

However, of the ACF sample, only $11 \%$ of families admitted to having working children.

A report by Terre des Hommes published in June 1996 and entitled Needs assessment of children working in the streets of Kabul estimated that 28,000 children were working in the street, particularly to provide their families with fuel and to earn some money through car washing, shoe polishing etc. This figure would tend to confirm the $11 \%$ estimate given by ACF. However, it has always been the norm for children over the age of about 9 to engage in some form of work outside the home, if it can be found, and the real figure could be much larger than the $11 \%$ stated. Terre des Hommes operate four drop-in centres for working children, catering for a total of 250.

\section{Remittances}

According to the ICRC study, less than $7 \%$ of families received remittances from family members living outside Kabul and none of those headed by a widow or a woman benefited from this source of income.

\section{Cost of a monthly family food basket}

The ICRC study calculated the cost of a nutritionally balanced food basket for one month, based on wheat, rice, potatoes, beans, ghee, tea and sugar and found this to be equivalent to about 5.6 times the monthly earnings for a family with only one working member and about 3.4 times the average monthly earnings for a family with two working members.

The ACF study found that the price of the food basket had increased 3.5 times between December 1995 and September 1996. It had then decreased by a third in October 1996 but had increased by $46 \%$ over the following two months.

\section{The selling of assets}

The ICRC study sought, inter alia, to assess the level of hardship on the basis of ownership of certain assets. These included bicycles, radios, carts, carpets and bread stoves. Of the sample, $19 \%$ of the 
displaced and $7 \%$ of the residents had none of these assets. ICRC found that more than three quarters of the families had sold at least one of their assets in the previous two to three months. Those who were poorer were said to be less likely to have sold possessions because they had less to sell and were consequently nearer destitution. The items most frequently sold were radios or other electrical devices, cooking materials, carpets, mattresses and jewellery.

The ACF study noted that there had been a sharp increase in the disposal of assets during the last quarter of 1996.

ACTED expressed the view that $90 \%$ of the goods on sale in the market were second-hand.

Dr Harry Jeane of the London School of Hygiene and Tropical Medicine indicated that, according to an in-depth study which he had undertaken, $80 \%$ of families were selling household goods to stay alive.

Terre des Hommes, which provides midwifery support and therefore has a relatively intensive knowledge of particular families, commented that there had been an obvious decline in the socioeconomic status of families and an erosion of assets.

\section{Borrowing}

Of the ICRC sample, $90 \%$ of families were indebted. Most (68\%) had borrowed from relatives and a further quarter were in debt to neighbours.

The CARE study found that $79 \%$ of the widows surveyed had loans. The average loan size was 250,000 Afghanis (approximately $\$ 10$ ).

\section{Reductions in food intake}

The ICRC survey found that families had progressively reduced their food intake over the previous few years. In particular, the consumption of meat, good quality rice, potatoes, beans, vegetables, fruits, sugar and dairy products had gone down. Bread, tea, onions and ghee were the staple diet of a majority of families.

The ACF study noted that $95 \%$ of families never ate dairy products, $90 \%$ eggs and $71 \%$ meat. $81 \%$ never ate fruit or vegetables other than onions or tomatoes. Bread was the main energy and protein source, making up $60 \%$ and $76 \%$ of the daily intake respectively.

It also noted that $14 \%$ of families had reduced their daily number of meals, resulting in $94 \%$ of these eating two meals per day, out of whom $48 \%$ had cut down during the last quarter of 1996. $60 \%$ of families were classified as having either an inadequate or a deficient ration.

In an interview with ACF, they advised that, based on a nutrition survey conducted in June 1997 , the acute severe malnutrition rate had reduced to $0.6 \%$, compared with $1.4 \%$ a year earlier, and attributed this to the expanded programme of supplementary and therapeutic feeding. They also noted that the global malnutrition rate was virtually unchanged, having increased from $6.7 \%$ to $6.8 \%$ and observed that the incidence might have been worse if it had not been for the feeding programmes. 


\section{The Situation of the Displaced}

\subsection{The Nature of the Displacement}

It appeared that much of the population of Kabul was in a constant state of flux. The insecurity created by the military situation across the country, combined with economic uncertainty and ethnic tensions, were leading families to draw on as many potential sources of income as possible. It was thus common for part of the family to be in Kabul while others were elsewhere. This strategy of dispersal was an important element of the economy but made it difficult to define, with any precision, the nature of the displaced population at any one time. The process of seeking to reach a definition was rendered more difficult by the absence of hard information and by the existence of widely diverging opinions and speculation as to whether a given element of the population might be present or not, and on what scale.

In order to provide a baseline for our consideration of displacement, it may be useful first to note the characteristics of the various neighbourhoods which make up the city. The maps incorporated in this report provide a useful reference point. On the map of Kabul and the surrounding area, the large cultivated area to the north is the Shomali Valley.

The capital is dissected by the Kabul river. To the immediate north, in the centre (District 2), are Government buildings and bazaars. To the north-west of this is what was previously the commercial area of Shahre Nau (District 4), now characterised by empty shops and agency offices, with a population of 126,265 (UNCHS Surveys: September 1995 to December 1996). North-West of this is the relatively affluent area of Wazir Akbar Khan (District 10), which contains diplomatic missions, agency offices and homes for agency personnel. To the far north of the city is Khair Khana (Districts 11 and 15), which has a particularly large population concentration and a total population of 319,401 (UNCHS).

To the west of the city is an area largely devastated by warfare (Districts 3 and 5), with a population of 51,855 . To the south is the District of Karte Se (District 6) with a population of 124,844 . Further east, in the south, are three districts which have also suffered widespread destruction (Districts 7 , 1 and 8). These, combined, had a population in December 1996 of 116,400. The three outlying districts of the north-east of the capital (Districts 10,9 and 16), by contrast, had a combined population of 297,238 .

I was informed of the following examples of population displacement:

1) An estimated 200,000 people had left the Shomali Valley at the beginning of the year, for Kabul. A further number had travelled north from the Valley to Pul-i-Khumri and Mazar. It appeared from a number of sources that a significant proportion of this group had returned to the Valley from the north, and from Kabul, after the northern part of it had been retaken by Masoud's forces in June 1997. There had been a particularly pronounced movement in preparation for the autumn harvest.

Many of those leaving Kabul had managed to find a way around the front line and had then remained for the winter. However, there was some movement backwards and forwards, exemplified by people travelling from the Valley to Kabul for medical care and then returning, on which a number of agencies reported.

It appeared to be the case that parts of families had returned rather than whole families. This 
ensured that people had a home to return to, should fighting recommence in either Kabul or the Shomali Valley. It also enabled properties to be protected and maintained and the land to be cultivated. The part of the family in the countryside were able to benefit from lower living costs and extended family support. The part in the city had better access to health care and also had potential access to relief supplies. Further, with differential price levels in Kabul and the Shomali Valley, at least part of the family could benefit from the lower prices prevailing, wherever these might be. ICRC estimated that around $60 \%$ of the Shomali Valley population had gone back, including both those who had fled north and those who had travelled to Kabul.

ICRC advised, on the basis of two recent visits to Charikar, that the area was well populated, with all age groups in evidence, and that people were to be seen in significant numbers working on the land. The bazaars were also reported to be bustling and well stocked. ICRC had noted a marked difference in the situation as compared with that evident during visits earlier in the year, when it had been largely depopulated. UNOCHA also confirmed this picture, indicating that, on a visit undertaken to Charikar in April/May, the bazaar was full of people. Other sources indicated that some of the residents of the Shomali Valley had remained on their land throughout the year and that most of those who had fled north to Pul-i-Khumri and Mazar at the beginning of the year had since returned.

Most of those displaced from the Shomali Valley to Kabul had established themselves in the northern district of Khair Khana. A handful had subsequently moved to the extreme south of the capital, where it was possible to settle in damaged houses in what had previously been part of the front line between the forces competing for control of Kabul. This area also offered the potential for crops to be cultivated on derelict land.

2) Based on monitoring carried out by UNHCR, at the Pul-i-Charkhi checkpoint on the Jalalabad road, of families travelling with substantial baggage, an estimated 54,264 people had returned to the capital from Jalalabad between January and November 1997, most during the spring and summer. A further 24,678 had returned from Pakistan. Some of those from Jalalabad had previously lived in the IDP camps at Sar Shahi and New Hadda. Others had been in the city. A proportion of the returnees were among those working to rebuild houses in the devastated southern suburbs. Others were recorded to be heading for the district of Microrayon in eastern Kabul, which contains a large area of prefabricated housing blocks blackened from rocket attacks. Yet others said that they were going to Khair Khana.

3) A total of 90,982 people were recorded by UNHCR as having left the city via the Pul-i-Charkhi checkpoint between January and November 1997, of which 29,838 had travelled to Jalalabad and 52,574 to Pakistan. The greatest movement had been during the autumn months. There had thus been a greater number leaving the capital than returning, with a marked flow to Pakistan. There had been particularly large concentrations from Microrayon (District 9) and Khair Khana (Districts 11 and 15).

If one takes as a baseline the population figure estimated by UNCHS as at December 1996 of $1,101,889$ and adds to this the balance of inflows and outflows recorded by UNHCR at the Pul-iCharkhi checkpoint on the Jalalabad road, one reaches a figure of $1,089,849$. Assuming that approximately half the Shomali Valley population which entered the capital in the early part of the year, representing parts of families, are still in the city, one ends up with a population of around 1.2 million.

4) A consideration of UNHCR figures of families leaving and returning to Kabul since its monitoring began in early 1995 indicates a massive flow of population in and out of the capital. Thus, a total of 404,629 people had returned to Kabul and 240,958 had left. Out of the 404,629 
returnees, 90,981 had gone to Microrayon in District 9, the area of government-built prefabricated apartment blocks, 59,142 had returned to Khair Khana. 33,132, had gone to District 8 , one of the heavily destroyed areas in the south and a further 33,918 had gone to Shahr-e-Nau (District 4) in the centre of the city.

Of those who had left the capital, 44,901 had departed from Microrayon, 41,284 had left Khair Khana, 15,443 had gone from District 8 and 22,915 had left District 4. These figures indicate that people were more likely to have left the previously middle class areas, having returned, than the more destroyed areas and suggest that those who used to earn a reasonable living now have other sources of income elsewhere which make it possible for them to leave. They also suggest that the previous middle classes are, by and large, deciding that they cannot survive at an adequate level in Kabul at the present time and this tends to reinforce information coming from other sources that, of those left in Kabul, even those who have worked in professional occupations are surviving at an extremely basic level.

Another way of looking at the figures is to compare the destroyed area with that which is largely intact. The combined population of the districts which are not seriously damaged, primarily in the northern segment of the capital (Districts 2, 4,10,11 and 15), was 619,209 (UNCHS figures) and that of the destroyed area 482,680. Of those returning, 201,598 were from the intact area (together with District 16) and 193,567 were from the destroyed areas (excluding the figure for District 16). This indicates that the destroyed areas contain a greater proportion of returnees.

Looking at those who have left the capital, the numbers from the intact areas have been 124,107 (together with District 16) and from the destroyed areas, 111,247 (excluding the figure for District 16). Again, there has been a higher proportion leaving the destroyed areas than the intact areas but the difference has not been as marked as with those returning to Kabul. Taking account of the high rate of departure from the previous middle class areas, this could suggest that it is more difficult for those who have returned to destroyed areas to go elsewhere. Those returning to destroyed areas, many from Jalalabad, are likely to be poorer on average and, therefore, less able to look for economic opportunities elsewhere. There was nonetheless, as indicated in (3) above, an apparent flow of people in 1997 travelling to Kabul and then moving on to Pakistan. A comparison with the figures dating back to 1995 and the figures for 1997 also indicates a very marked reversal of the return process of the initial period. Thus, over 1995-6, 325,687 returned to the capital while 149,976 left. By contrast, during 1997, 78,942 returned while 90,982 left.

5) There was a seasonal movement of people with the necessary means who would spend the winter in Jalalabad and the summer in Kabul. However, here again, we may not be talking about whole families on the move.

6) Following the pattern evident in the rural areas, young people would travel to Pakistan or Iran to seek work, to escape conscription or for security reasons.

7) Abut 3,000 people had recently left the Ghorband Valley, to the north-west of Kabul, to escape from fighting between the Taliban and Hisb-e-Wahdat. It was thought that some of these had since travelled on to Jalalabad, Pakistan or southern Afghanistan.

8) UNHCR monitors reported that families were coming in to Kabul from northern Afghanistan, to escape from the recent fighting and insecurity around Kunduz in particular. It was not known how many of these would remain in Kabul and how many would travel south, to Kandahar and other Taliban-controlled areas. 
9) There had been significant movement within the city. The ICRC Mission report produced in December 1996 found that six out of ten people in a particular district in southern Kabul had moved three to five times during the conflict.

10) It was thought that most of those originating in Wardak, Charasyab and Logar had returned to their villages after the Taliban had taken Kabul in September 1996.

11) There are temporary movements, e,g. some work on the land during the summer and spend the winter in Kabul; some move in with relatives for the winter to save on fuel.

Drawing on these figures and on information gathered from other sources, one can note additional patterns. Thus, the Khair Khana area has close links with the population of the Shomali Valley but it has also accommodated large numbers from the southern Districts of Kabul in the past, as these have fled from rocket attacks and fighting. Some of these have since returned to the south. One can also note that the Hazara populations of Karte Se (District 6) and Taimani (in District 4) are relatively settled. To summarise, with the possible exception of the Hazaras, it has been a highly fluid population, with whole families, or parts of families, moving in and out of, and within, the capital in response to economic conditions, fighting and seasonal climatic changes. Groups have also passed through, en route from conflict situations to the safety of areas providing greater security.

\subsection{Provision for the Displaced}

ICRC has accepted responsibility for providing relief supplies to the internally displaced. When the Shomali Valley was evacuated, ICRC resisted requests to establish a camp for IDPs, taking the view that it would not want to create conditions which might inhibit return at the earliest possible opportunity, particularly given that the evacuation of the Shomali Valley had been a conscious strategy of war on the part of the Taliban. ICRC opted, instead, to provide relief supplies to those who found their way spontaneously to public buildings, assuming that those who did not pursue such an option would have found accommodation with relatives.

Plastic sheeting was provided for the public buildings occupied, because of the absence of glass in windows, and, in addition, each family was given a one-off allocation of $50 \mathrm{~kg}$ wheat, $24 \mathrm{~kg}$ rice, $18 \mathrm{~kg}$ beans and $9 \mathrm{~kg}$ ghee. If a given family was still in the same building a month later, the same allocation would be given. A few families were found to be present two months after the exodus but the average length of stay was one and a half months. 8,000 families had received these rations since the beginning of the year, representing approximately one quarter of the 200,000 people who had come to Kabul.

Because of the policy of not encouraging a semi-permanent settlement of IDPs from the Shomali Valley, this group were not included in the lists drawn up of potential beneficiaries for the various relief programmes of the humanitarian agencies. This was in spite of the fact that displaced people, as a category, were among those regarded as vulnerable for the purpose of targeting for relief programmes. It was only in August 1997 that a decision was taken that, in the context of a new survey, this group of IDPs should be included. IDPs from the Shomali Valley have, thus, been potentially in receipt of food and other goods distributed under the recent winter relief programme. Having said that, it was thought likely that some bias would have entered into the process of drawing up beneficiary lists, in favour of residents. It should also be noted that an element in the IDP population were said to be landowners, with businesses in Kabul, who were not, therefore, likely to be eligible for the distributions. 
The ICRC Mission report noted that resident families were more likely to have received assistance in the past than displaced people $(67 \%$ as against $53 \%)$ but that, during the previous month, there had been a greater allocation to displaced people ( $52 \%$ as against $44 \%$ ). The report commented that, within each group (IDPs and residents) people were being registered on lists in roughly equal proportions and indicated that, while IDPs did not appear to be securing preferential treatment by virtue of their potential vulnerability, they were no worse off than residents. 


\section{Appendix 1}

\section{Summary of Relief Provision by Agency (December 1997)}

The WFP/ACTED bakeries project provided for 182,644 people.

The WFP/ACTED widows' bakeries project provided for 28,290 people.

WFP supported food for work programmes, with beneficiaries rotating employment in order to provide an income to a greater number of families.

WFP supported institutional feeding in hospitals and in the orphanage.

ICRC delivered relief supplies to 30,000 widow-headed households which were not benefiting from the WFP/ACTED bakeries project.

ICRC delivered relief supplies to 1,500 disabled heads of households.

ICRC has supported 7,335 people through food for work programmes, working for between 20 days and three months each.

CARE delivered a one-off winter relief package of a combination of food items, including beans and oil, to 11,000 widow-headed households. MEDAIR provided a non-food distribution to the same 11,000 . Some of these were said to be on the WFP bakeries' list. 


\title{
Appendix 2
}

\section{Interviews undertaken in Mohammed Agha}

\author{
Man in his 30s, Nawabad Village
}

We returned ten months ago from the camp in Peshawar where we had been living. There are eight of us in the family. We have three sons and three daughters. My brother died last year and I am also taking care of his family, which consists of four people. We are all living in the same house.

I have a brother who is working for a farmer in another part of Mohammed Agha and I also have other relatives in the district. We all came together. None of the family are in Kabul.

I work as a farm labourer for other farmers, on a one third share-cropping basis. In my case, the landlord provides all the seed. For 50\% sharecroppers, the sharecropper provides some of the seed.

We have had a full harvest this year. I am farming 27 jeribs. I do not expect to cultivate any more land next year.

There is enough water. During the war, the canal was destroyed. However, CARE has cleaned the canal and also built a diversion dam and protection wall. When CARE first started, there were only a few people living here. Once the work started, people started to return.

There was no contact between us and CARE when we were living in the refugee camp. The people who had stayed behind in the village went to the district office of the local authority and asked if anyone could come to repair the irrigation systems and clear mines. The district authority contacted CARE and MCPA. The de-mining was carried out when Mujadidi was President (in 1992) and again after the Taliban had chased Hekmatyar out of Charasyab. There have been no mine accidents in the residential area but three people were killed when collecting wood at a military post on a hill which hadn't been cleared.

We haven't sent any of our agricultural produce to Kabul but we are sending onions to Pakistan, where they fetch a better price. Others in the district are sending wheat, onions, potatoes, corn and vegetables to Kabul but most potatoes and onions are going to Pakistan.

We were in Pakistan for 15 years. We decided to come back because the area is peaceful. Pakistan was boring for us. I could only get work for two or three days per week. We hadn't been receiving rations for several years and wages for labouring were very low.

My brother was shot in Pakistan. He used to sell clothes from village to village. He was killed because he had not paid his debts. I was here when I heard the news of his death. I had come on alone to cultivate some of the land.

I came here a number of times during the period of the Soviet occupation, and during Najibullah's time, to fight as a Mujahid. After the Mujahidin takeover (in 1992), I came from time to time to look at the possibilities for cultivation. The decision to come back was based on a combination of the increasing difficulties I was facing in Pakistan and the work undertaken to improve irrigation and clear mines. 
There are a number of organisations working in the area but I am not aware of their names. I am not even sure which organisation has helped me with the re-building of this house. I wasn't able to manage on my own because the materials were too expensive.

Before the war, my father and uncle used to buy and sell animals. My father had 7 jeribs of land but this was divided among the brothers. I have two thirds of this, where I have built my house. There used to be enough food for us. We left because of the fighting.

We have no major problems at the moment but it would be better if my brother's family had a separate house. My other brother doesn't have his own house either. He is living in someone else's house.

Quite a few people from the district have businesses in Kabul. For example, they take onions to sell in Peshawar and buy wheat flour and cooking oil from Pakistan and sell it in Kabul. Wheat flour was 35-45,000 Afghanis per kg last year. Now it is 55,000.

I go to Kabul to buy tea, sugar etc. I don't know anyone there. The economic situation in Kabul is very bad.

A lot of people from Mohammed Agha are living in Kabul. These are the wealthier people. They have land here and also have businesses in Kabul. Some have more than 100-200 jeribs of land and get others to cultivate it while they run shops or stores in Kabul or sell cars. Some of them bring vehicles from Torghundi or Herat and sell them in Kabul or Pakistan. A number of them are also government employees. There are two or three people here with a lot of land and they have houses in Kabul as well. These individuals could be the second or third richest people in Kabul. One of them has a factory in Jalalabad and a factory in Peshawar. He used to sell clothing but got involved in the heroin trade and is now very rich. He doesn't have any factories in Kabul but he sells cars there.

\section{Old man, Mohammed Agha village}

I was born here in Mohammed Agha but went to Kabul during Zahir Shah's time and worked as a cleaner in a government office. We stayed in Kabul throughout the war, living in the Chilsitun area. We didn't have enough money to go to Pakistan. We were renting a house there. I came back to Mohammed Agha five years ago when I retired.

My father had four jeribs of agricultural land but, when he died, my cousin married my mother and prepared a document which deprived me of my inheritance. However, I own the land that this village house is on.

Before I went to Kabul, I used to work as a daily labourer, helping with house-building. When we first came back, we lived somewhere else in the district and I used to come here to gradually work on rebuilding my house. However, I was finding it a struggle but then heard about the UNHCR programme and applied for assistance. My wife and 12 year-old son have helped me with the building. It's not a wonderful job. The walls aren't straight, but it's the best we can do. We have three young children, of 12, 10 and 7 and we are also looking after the children of another son who was killed two years ago by a rocket in Kabul, while he was staying with his father-in-law. His wife has remarried and left us with the children.

I worked as a sharecropper on a small piece of land up until two to three years ago but I now take care of the mosque and collect bread from house to house in payment for this. The community could see that I wasn't able to work so they asked me to take on this job. 
I have some relatives in Kabul, in Chilsitun. One is working as a daily labourer. One is a mechanic. One is a government employee and the other has gone to Iran this year. He was a driver and took two of his three wives with him to Iran. He was a commander of Masoud's and went first to Pakistan when the Taliban came and then went to Iran this year. The brother who is a labourer is helping with road reconstruction whenever agencies are working on the roads. He has a wheelbarrow.

There are young people from here working in both Pakistan and Iran - mostly Pakistan. There are around 70 families in the village and roughly one person per family is working in Pakistan. Some families spend the summer here, working on other people's land and then, in the winter, when it is impossible to find work here, they take their families to Pakistan. Some people have gone back to Pakistan permanently, either because they couldn't survive here or because they couldn't find somewhere to live.

I go to the mountains to collect wood for the winter. There are no mines. People would tell me that there were mines but I would say that God would help me. I used to also collect old iron to sell but the Taliban have stopped this.

\section{Middle-aged man, Mohammed Agha village}

We returned from Pakistan three years ago. There are thirteen people in the family. I have seven children and my brother and two sisters are with us. My brother went to Pakistan recently to look for work. If he finds a good job, he will stay. Otherwise, he will come back next year. He is looking for work as a labourer. He is about 22 years old.

I used to be a driver but can't find work. Sometimes, I work as a daily wage labourer in the village, sometimes outside the village. It is also difficult to find work in Kabul, but, if there were opportunities, I would go there. There are none at the moment. There is some private construction work in Kabul and there are some brick-making factories but it is very difficult to find a job. Because we have no agricultural land, the best place to be is where there is work. It is even difficult to get sharecropping work.

We left Pakistan because I lost my job as a driver and couldn't find anything else. I haven't gone back since. Sometimes, I work as an agricultural labourer. Sometimes I do construction work - but there are a lot of difficulties. However, I still had to pay other people to help me with rebuilding my house. It is too much for one person.

Young people go to Pakistan and Iran to look for work. This week about 30 went. One is planning to work in a brick factory in Pakistan. However, most are going to Iran. In Iran, the daily wage is higher but they have to pay six million Afghanis to be smuggled into Iran.

I was living here in Daoud's time. We left for Pakistan 14 years ago, when our homes were bombed by the Russians.

Before the war, I worked as a driver. At that time, it was easy to find work in other provinces. Sometimes I would work in Kabul and sometimes in other parts of Afghanistan. No-one worked in Pakistan in those days.

Most people in the village have returned from Pakistan rather than Kabul. Most have returned since 1992. People have built small diversion dams and culverts. There is enough agricultural land but there isn't enough water for it. A number of agencies have worked in the village. The Swedish 
Committee have done some repair and improvement work on the school. DACAAR has worked on hand pumps. UNHCR has given assistance with house building, including my house. CARE has worked on retaining walls and diversion dams. They don't have enough money to tackle large diversion dams so they only work on small ones. The agencies normally have discussions with the elders. The quality of the work is good. The local authority asks the community to evaluate the work of the agencies so they have to do a good job.

The Russians behaved very badly here. In this village, they killed about 400 people in bombing raids and by shooting them. They use firing squads, just as Abdul Malik has done with the Taliban in the north. The Russians killed more than 5,000 in the whole district. People left because of this. I used to come and fight here both during the Soviet period and while Najibullah was in power.

Dostam also killed people here during Najib's time. They even killed cows. There was no fighting in this immediate area after the Mujahidin took power in 1992 but there was fighting on the front line between Hekmatyar, Dostam and Masoud. When the Taliban came, they brought peace. Up until then, there was no security. There was looting. It was difficult to carry money. The main thing was that the Taliban collected up weapons. Before, if anyone had a gun, he was King. The elders could do nothing. Their sons were not obeying their orders. 


\section{Appendix 3}

\section{List of those interviewed}

International Committee of the Red Cross (ICRC)

World Health Organisation (WHO)

ECHO

Dr Harry Jeane, London School of Hygiene and Tropical Medicine

CARE

Action contre la faim

MEDAIR

Oxfam

Children in Crisis

United Nations High Commissioner for Refugees (UNHCR)

World Food Programme (WFP)

PARSA

UNOCHA

UNCHS

Terre des hommes

ACTED 


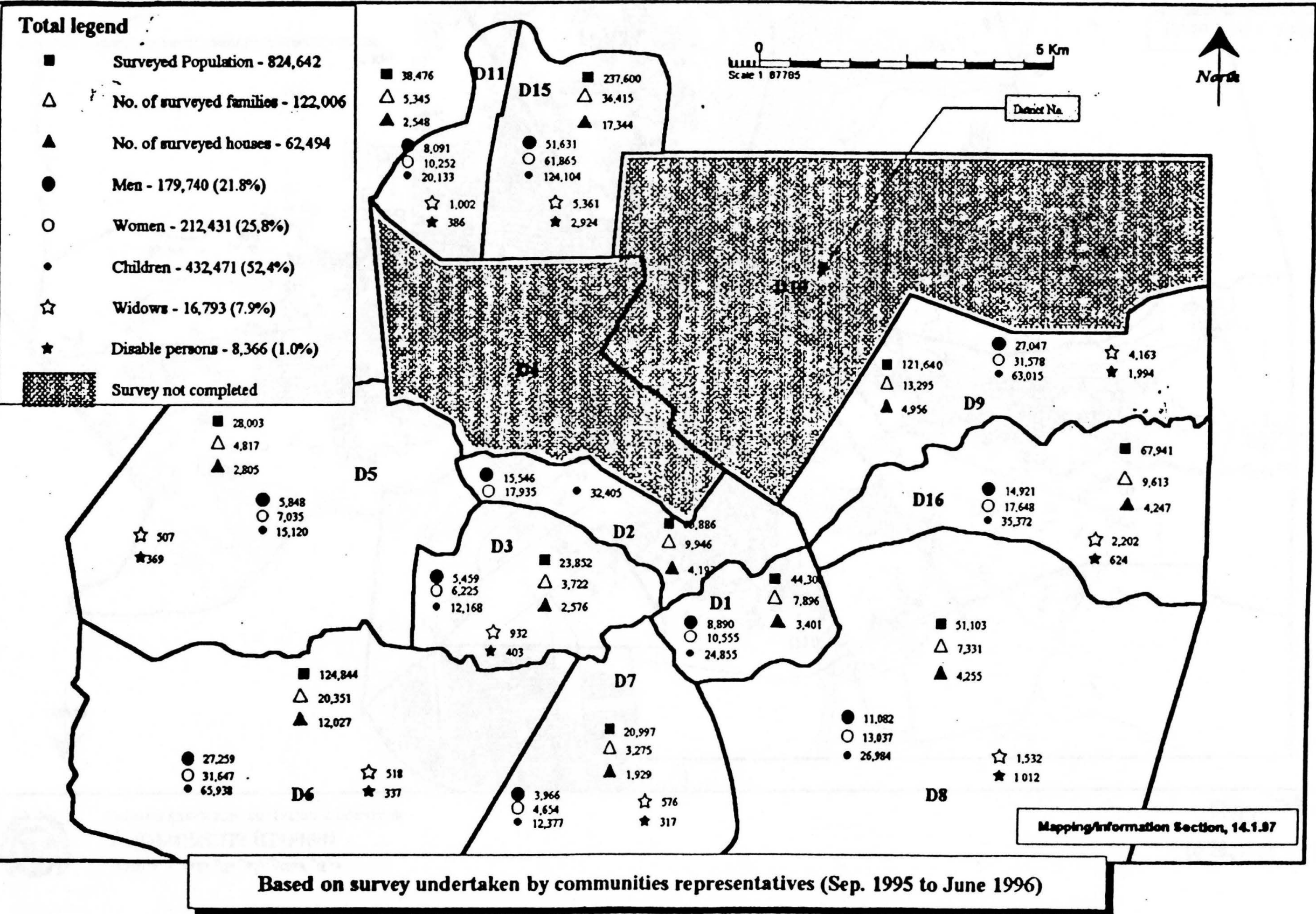




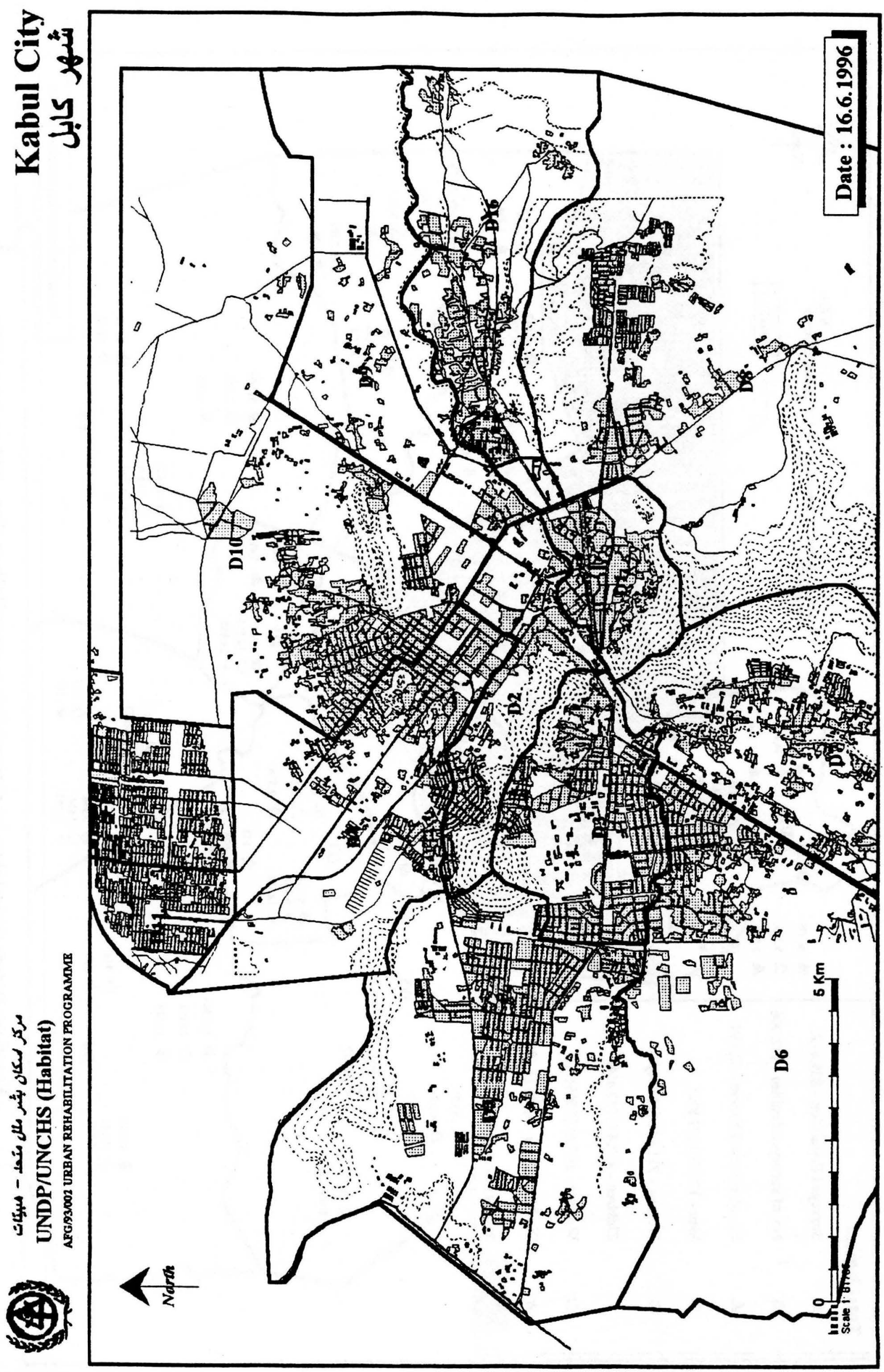




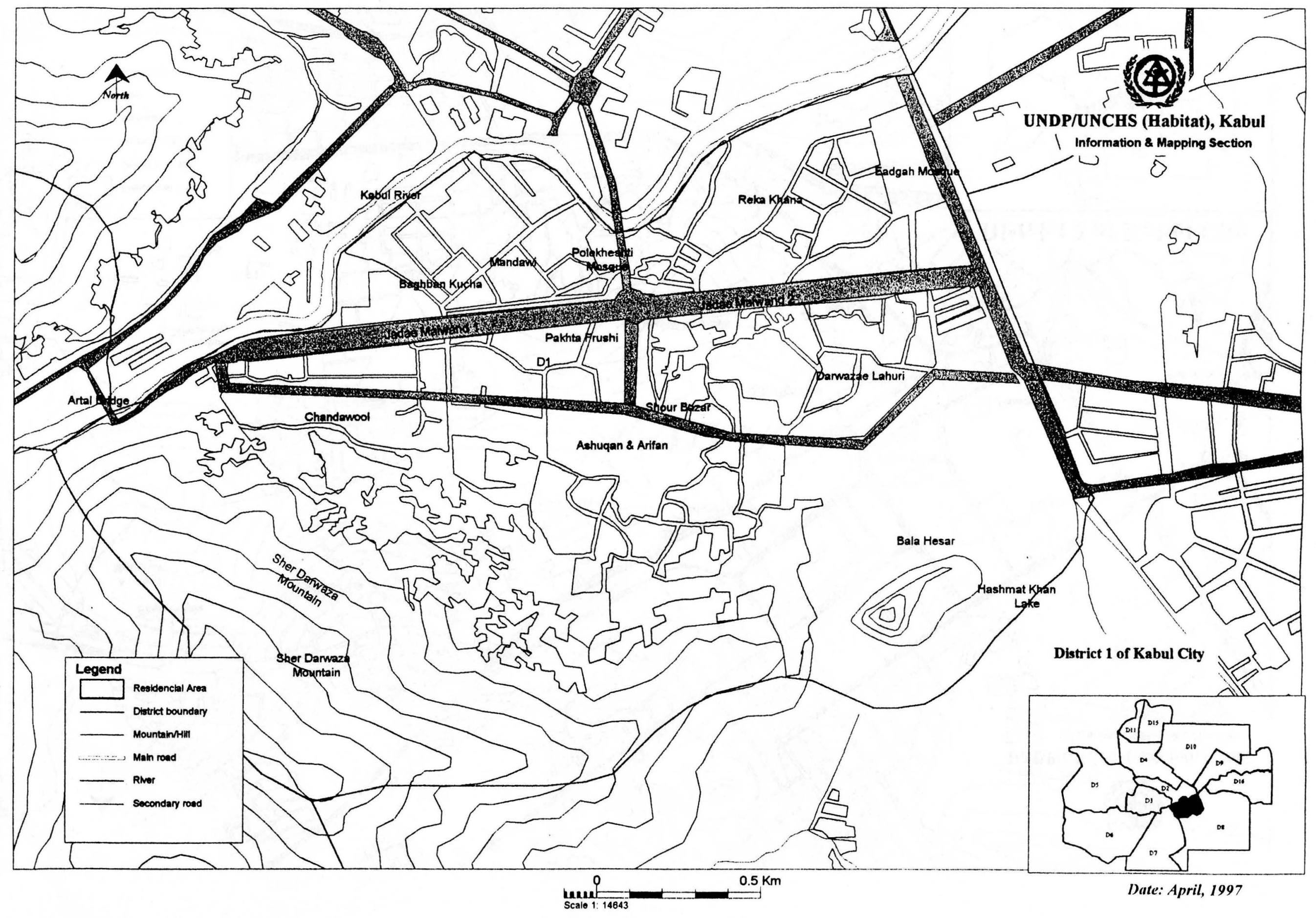




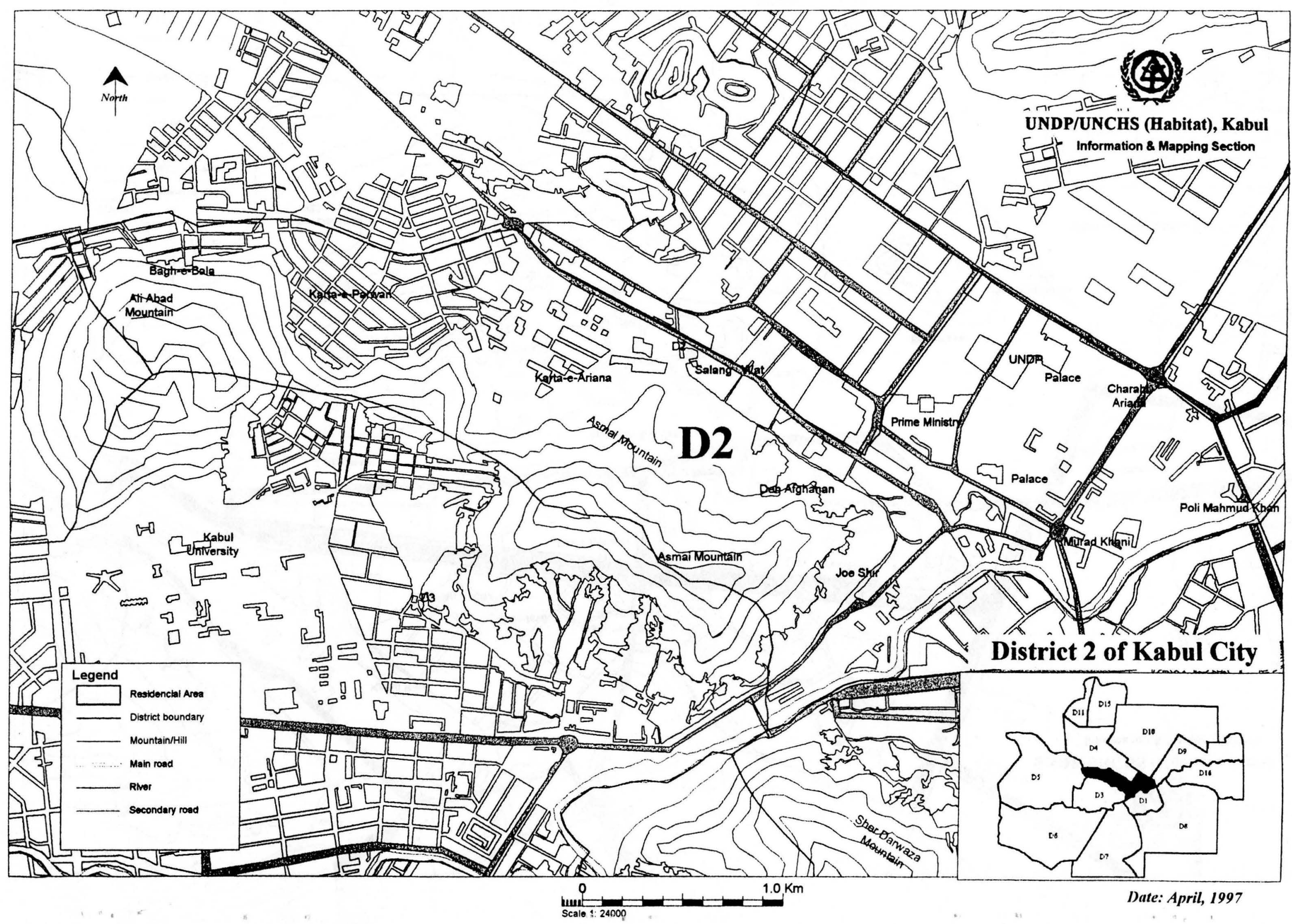




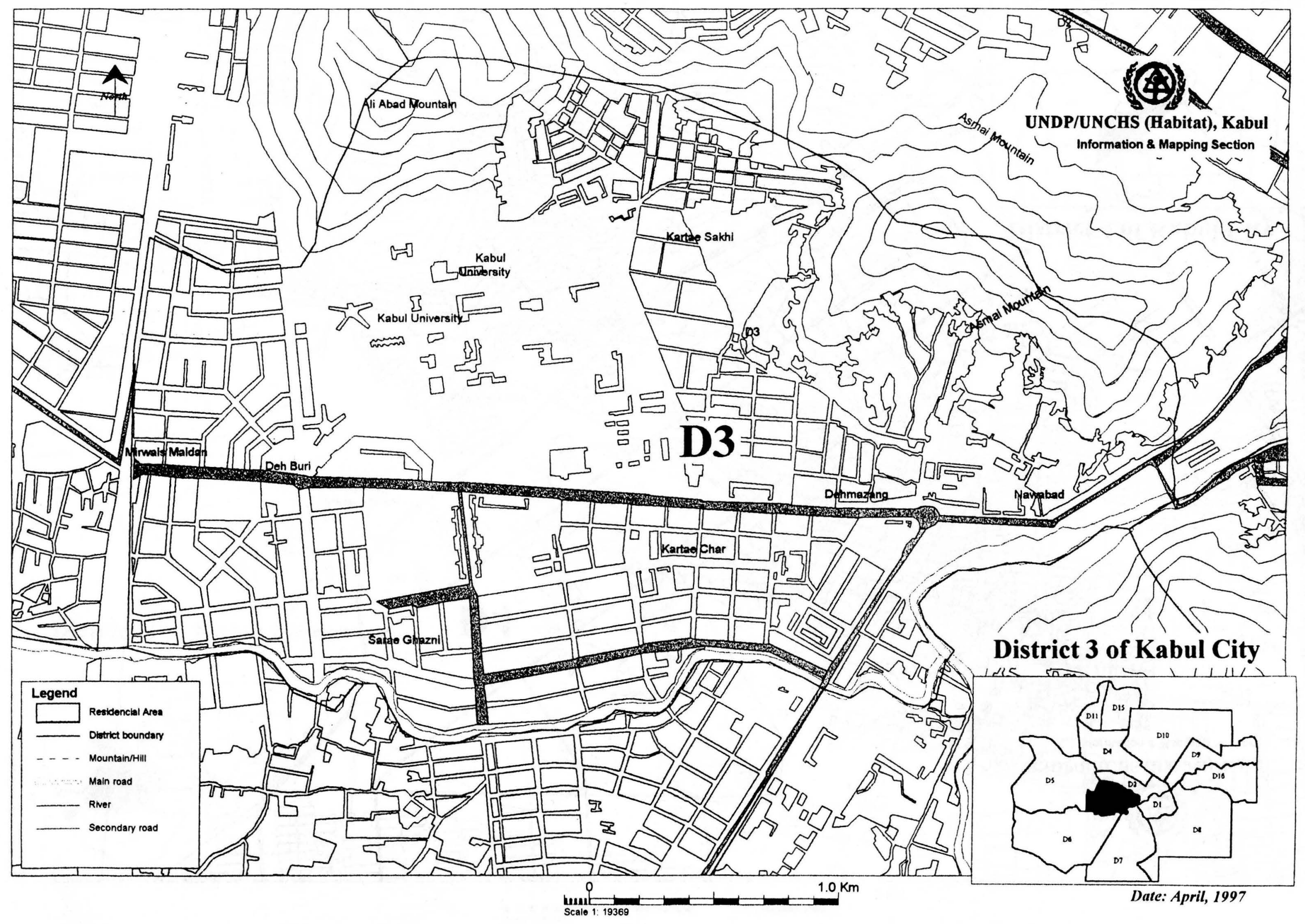




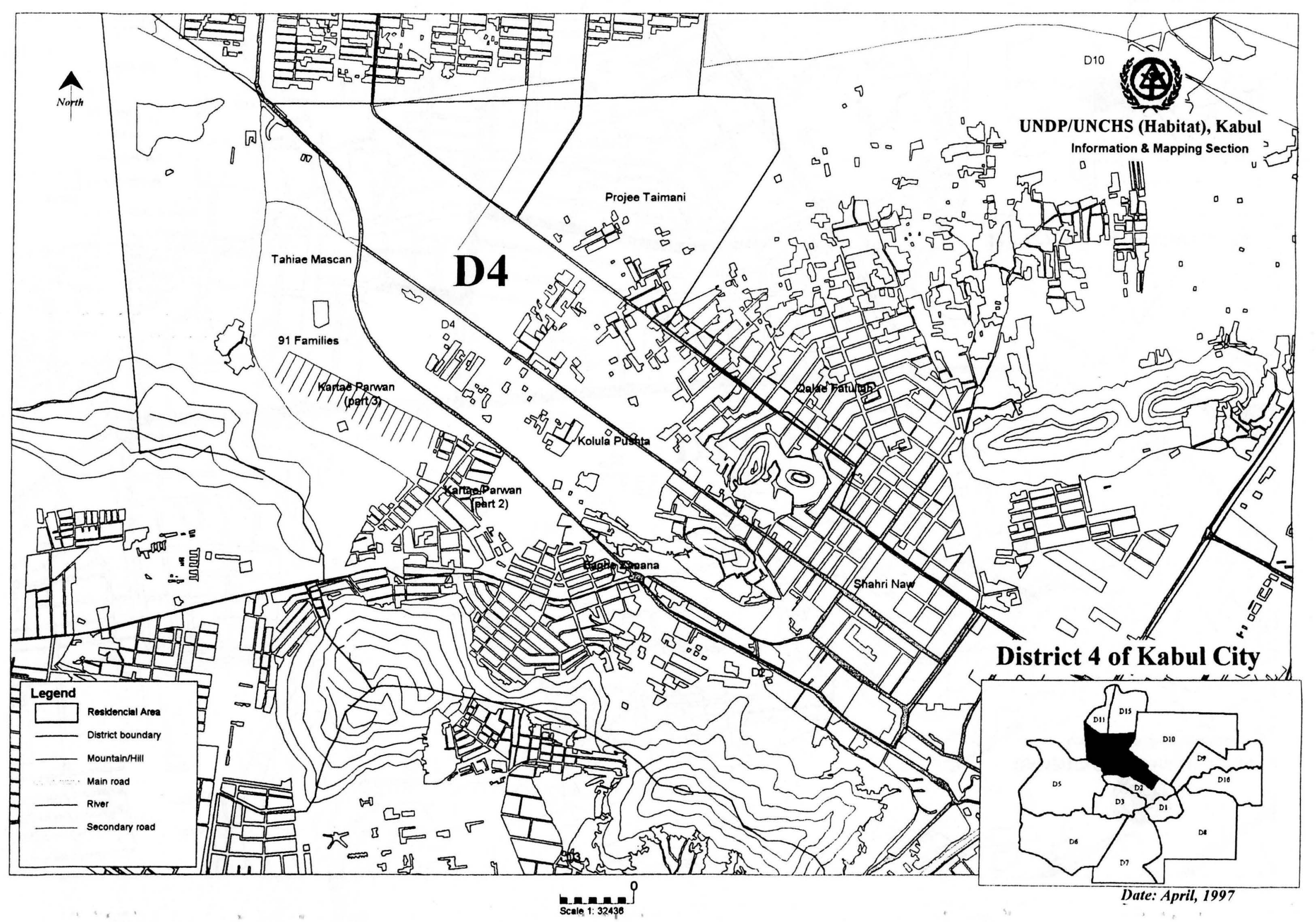




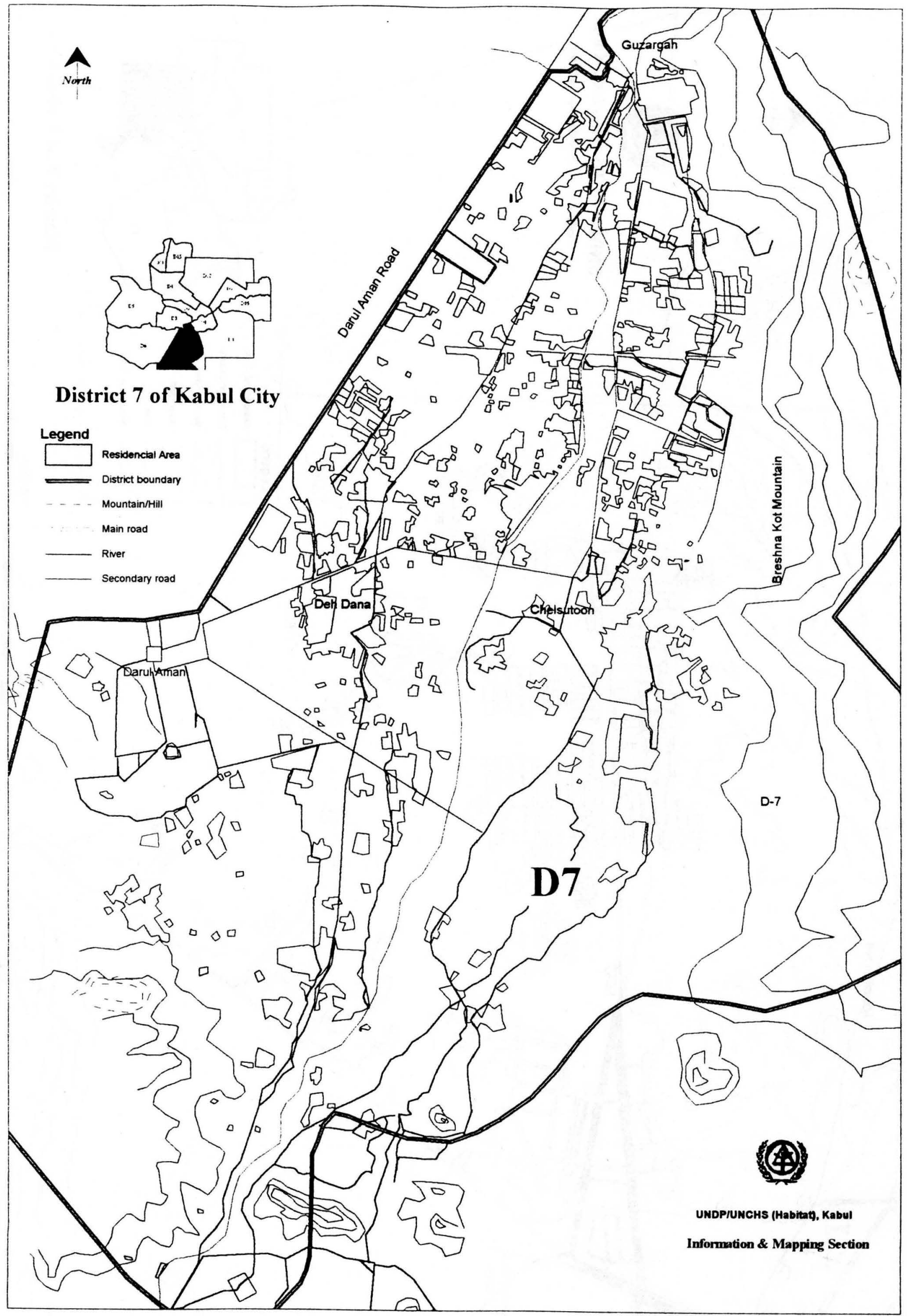




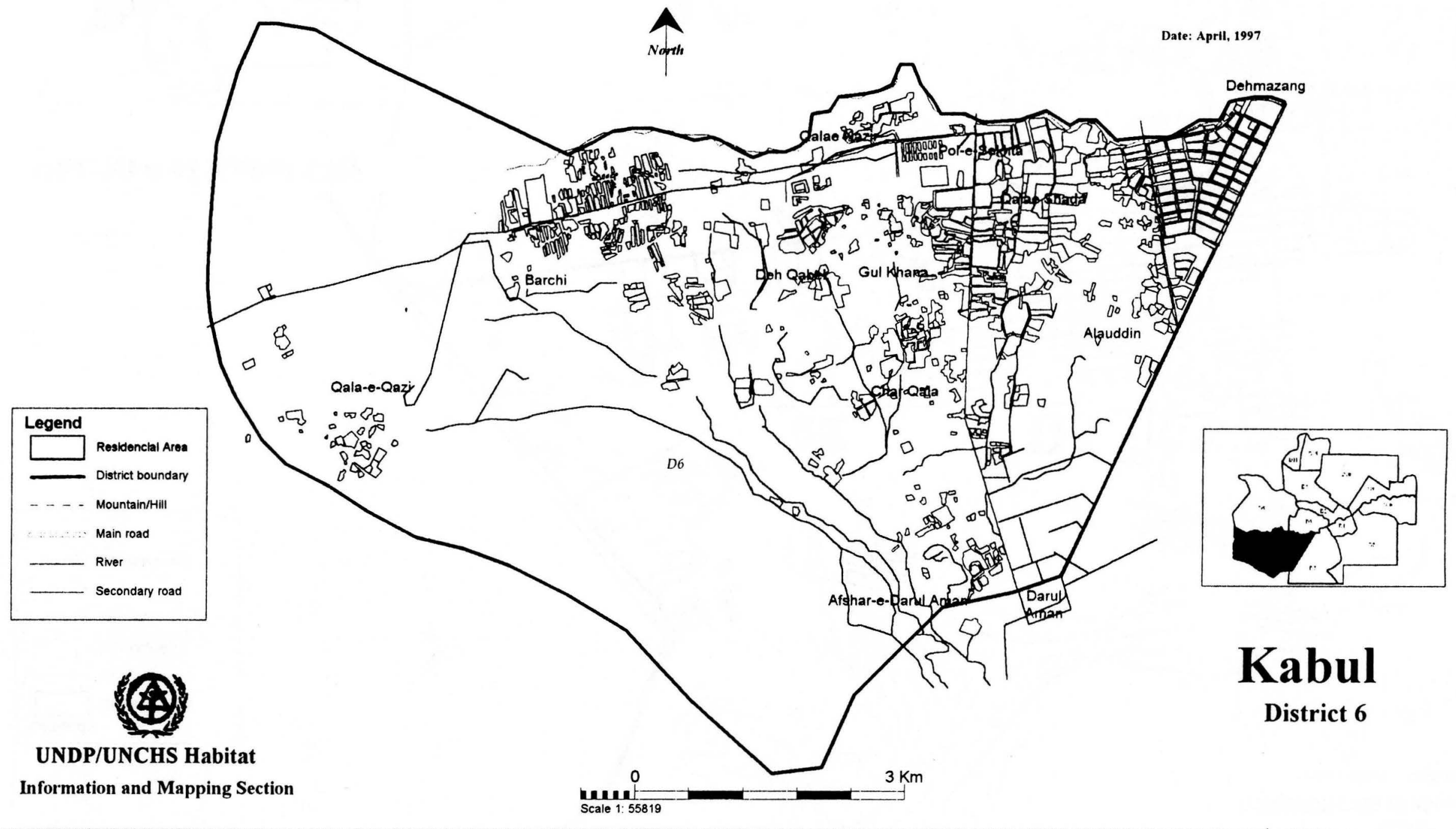




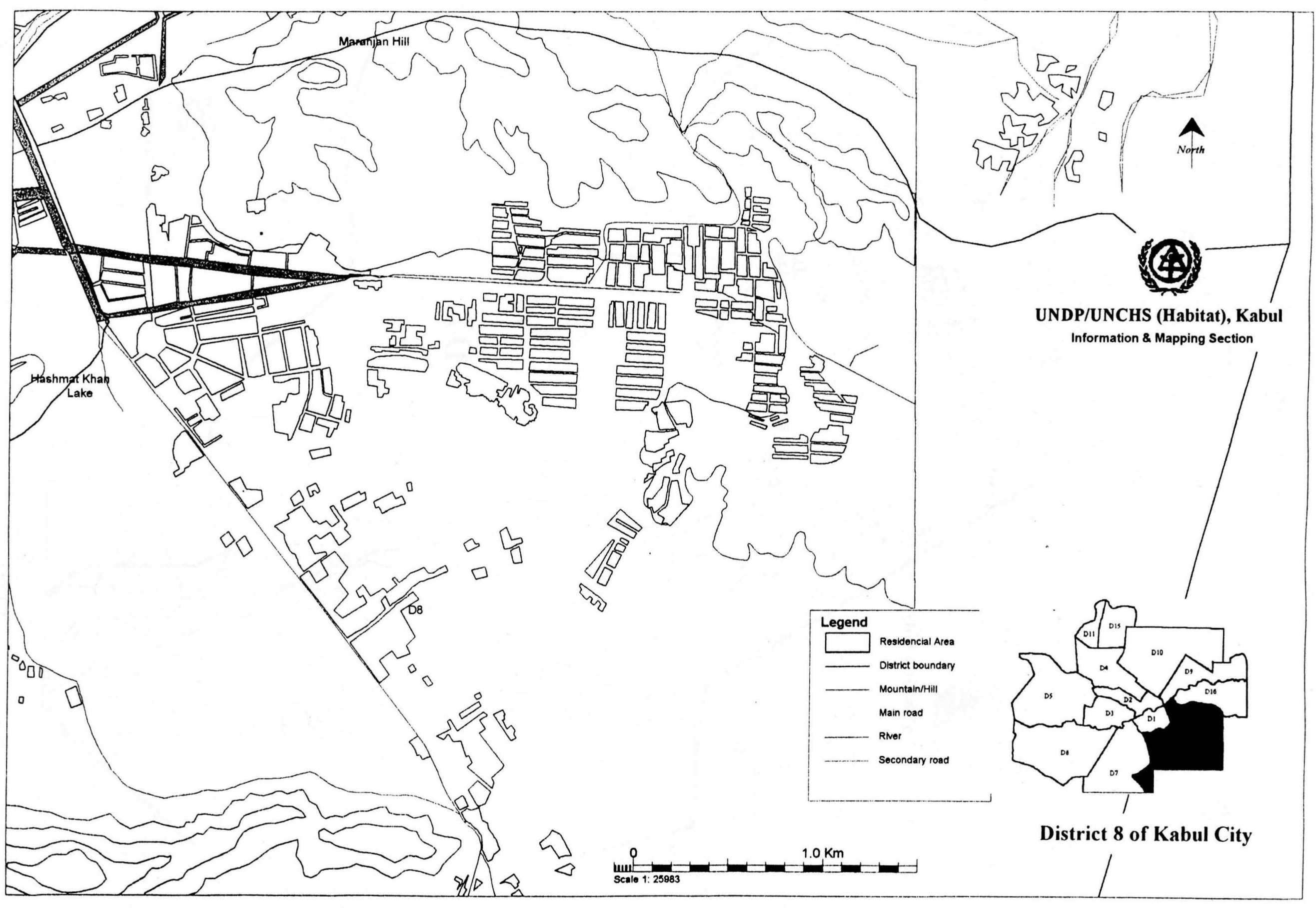




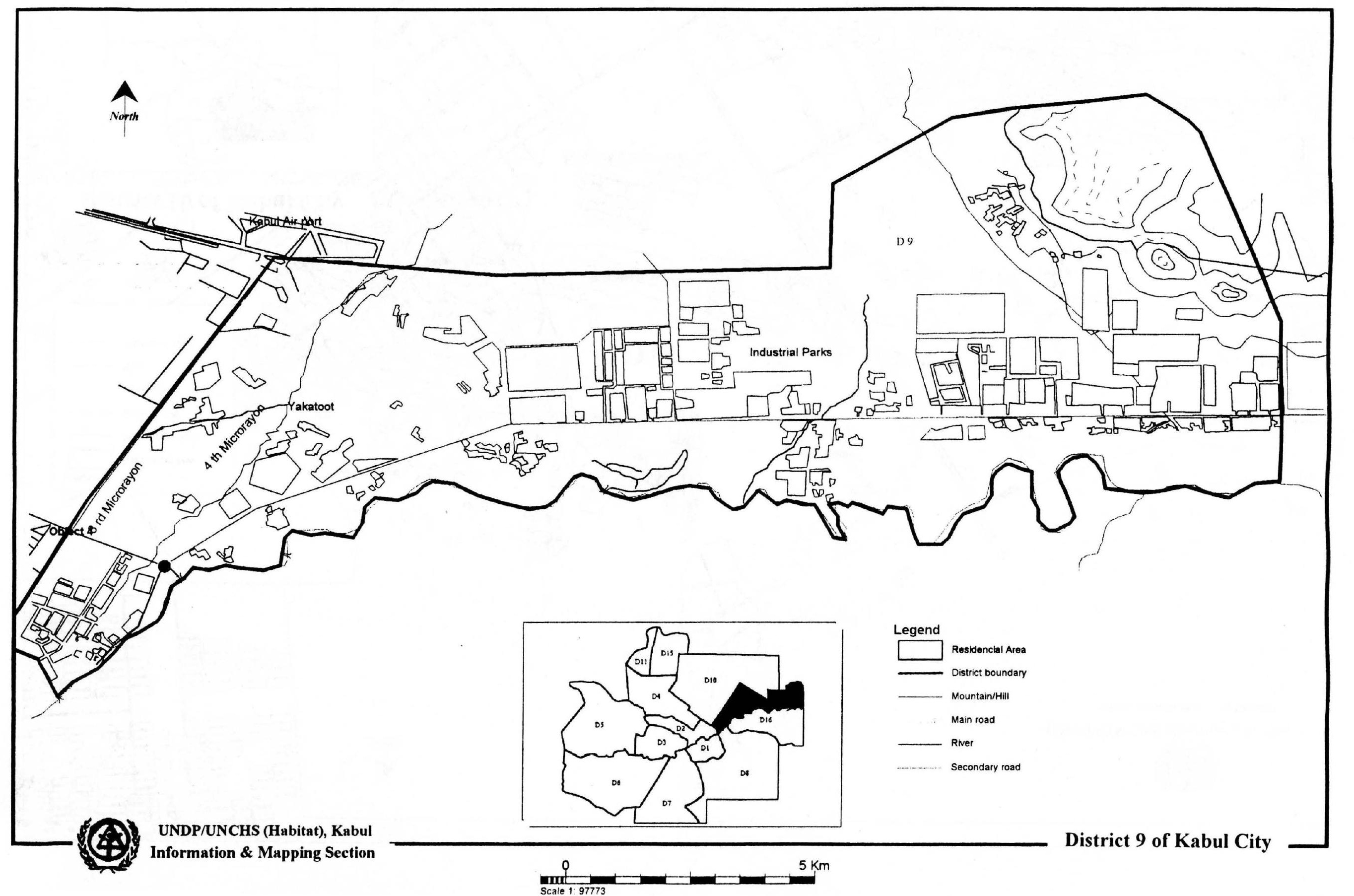




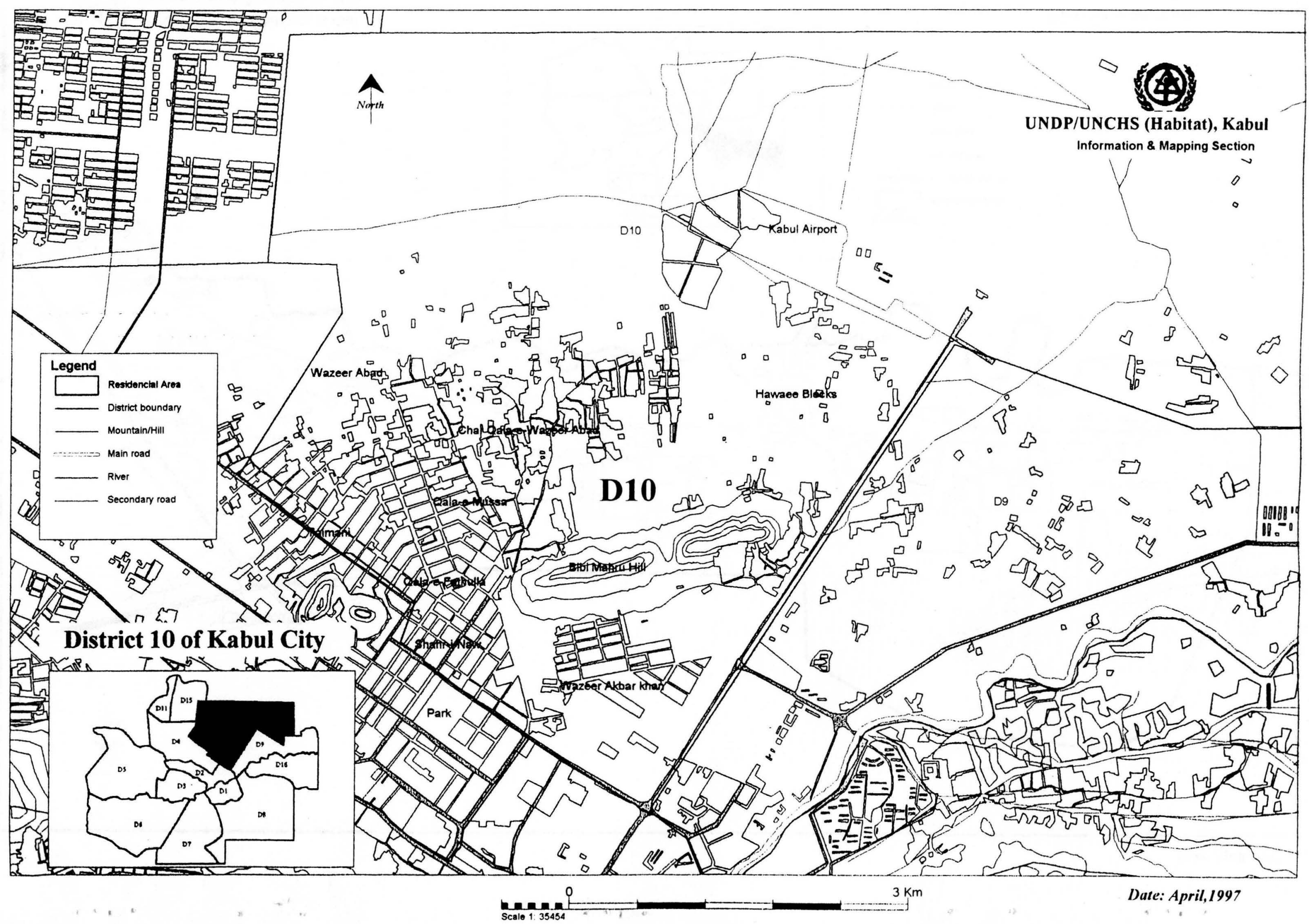




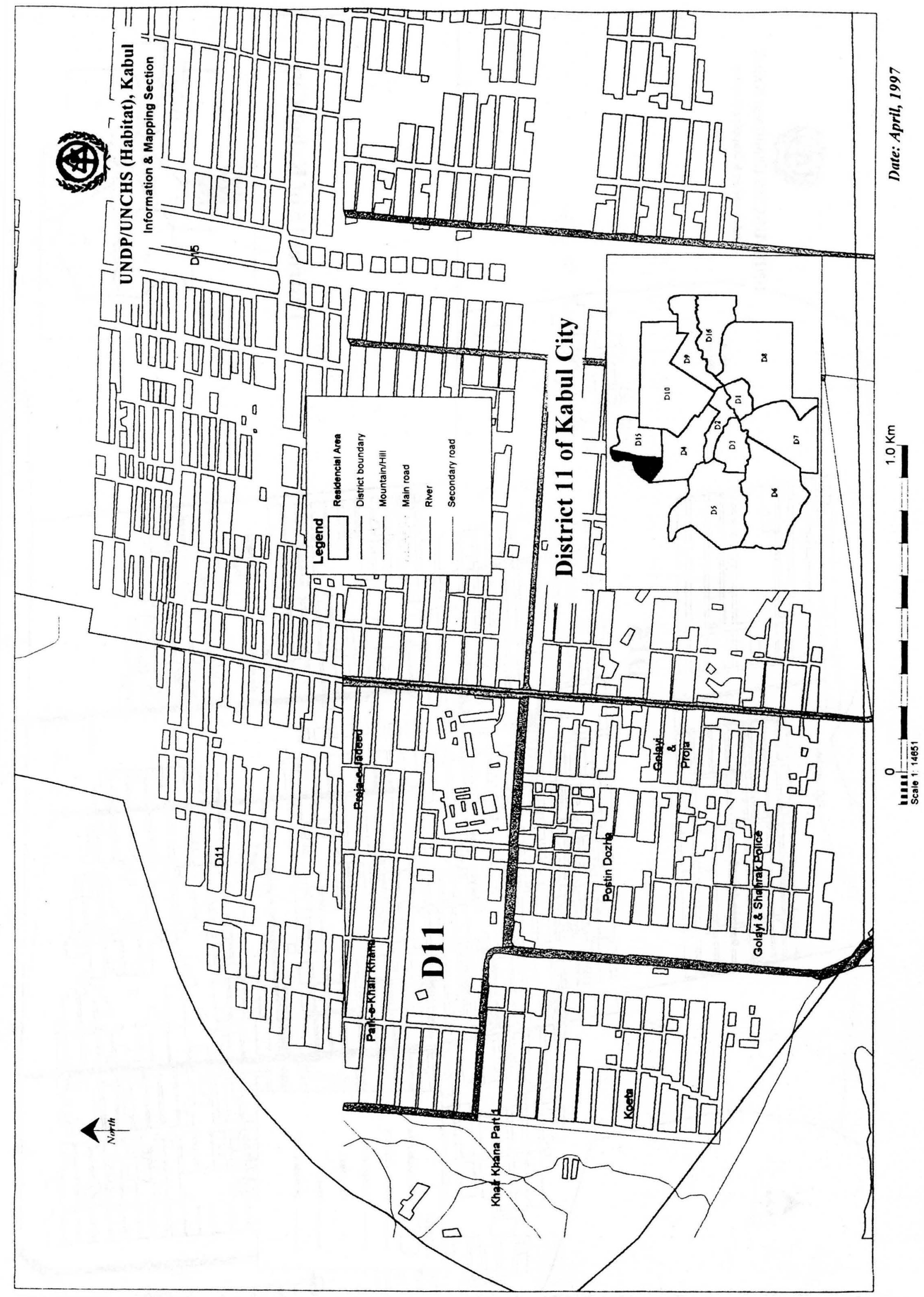




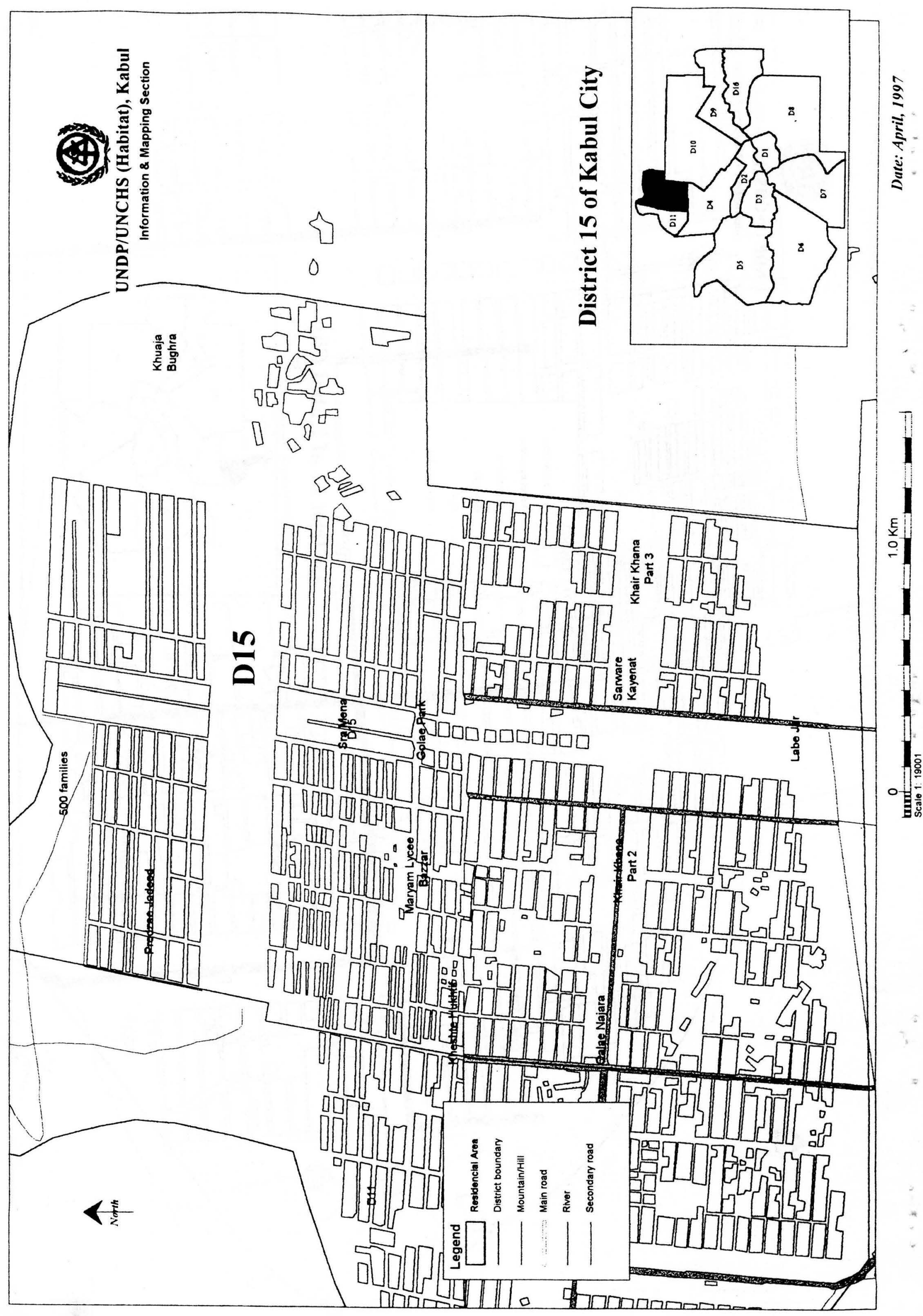


Date: April, 1997

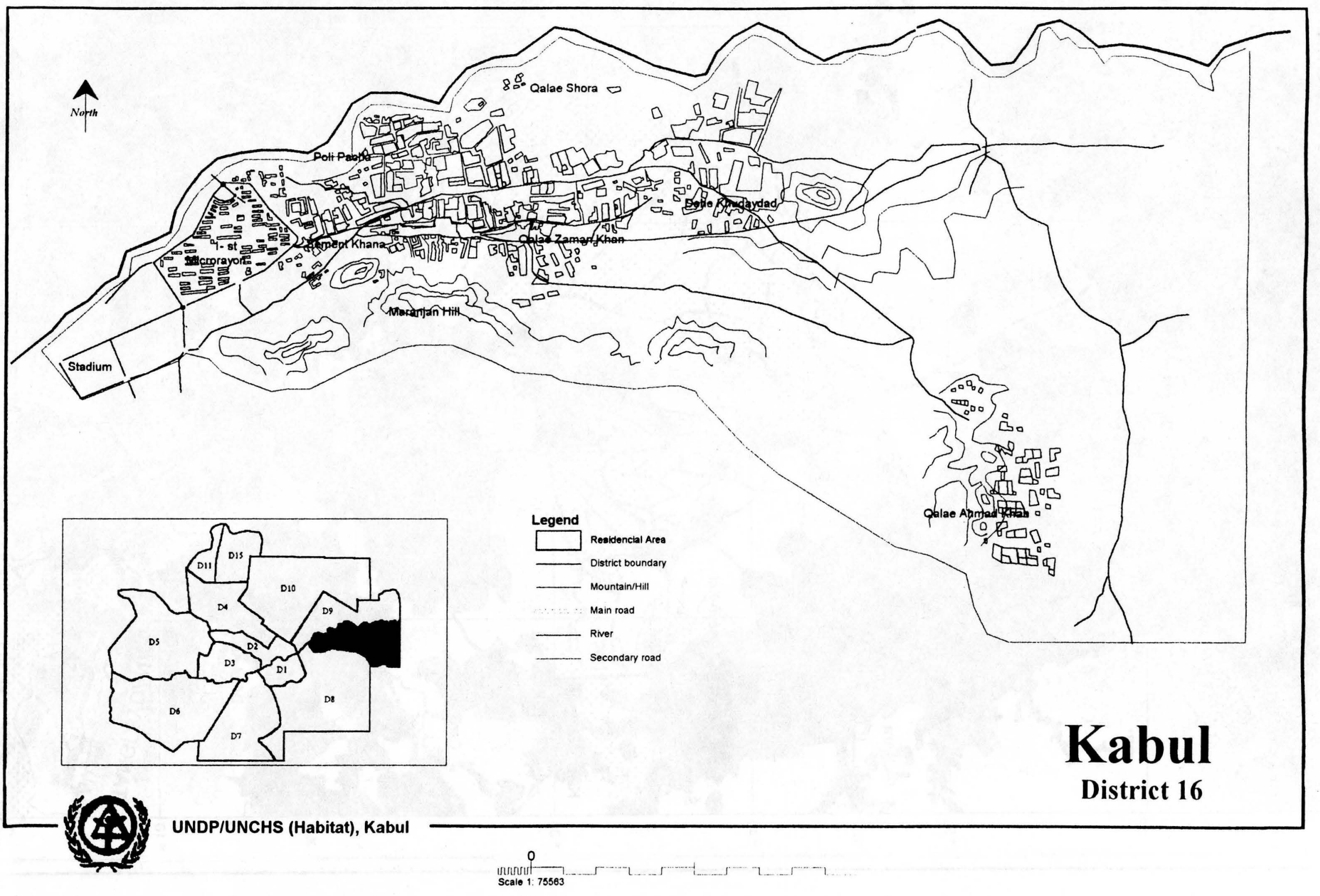




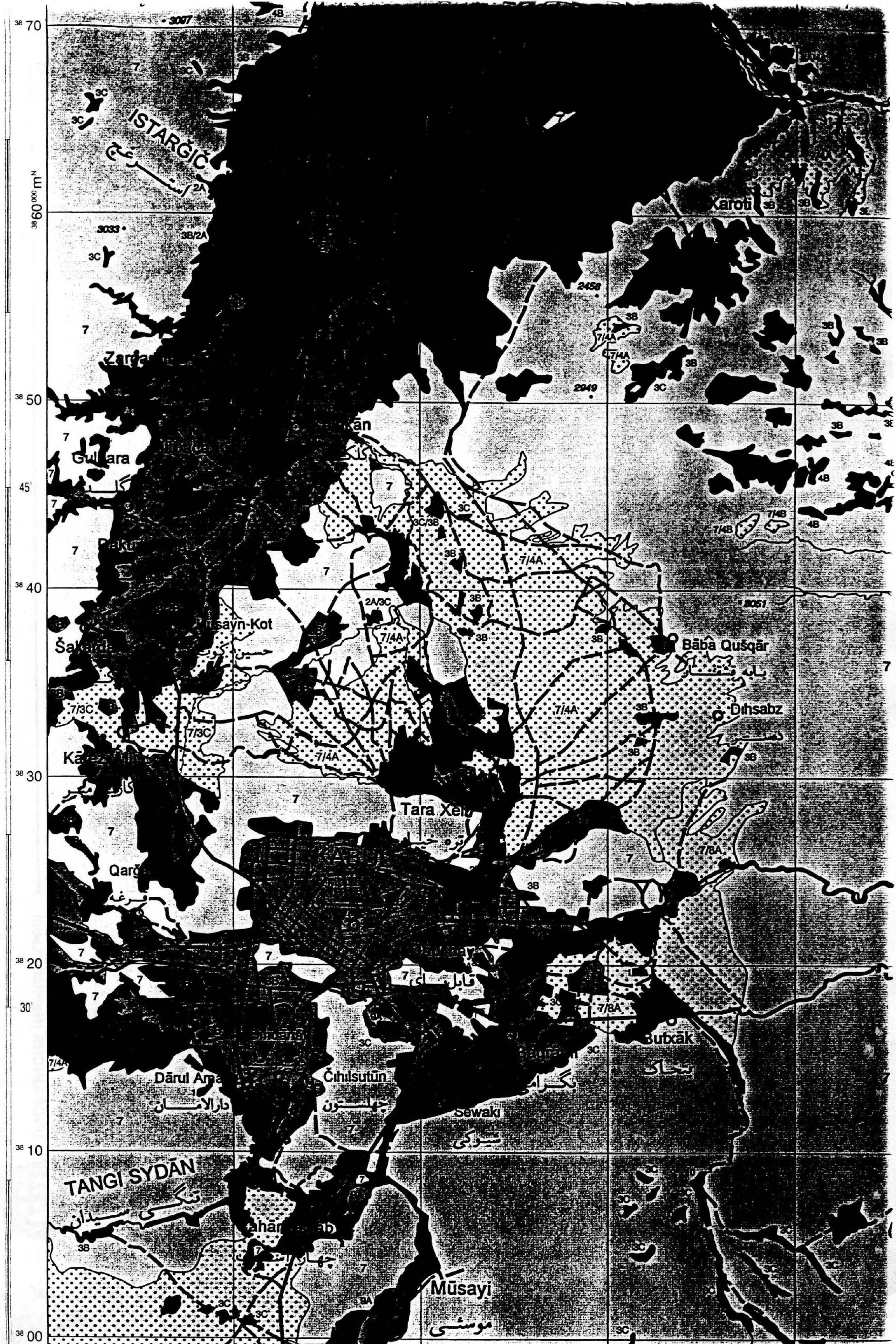




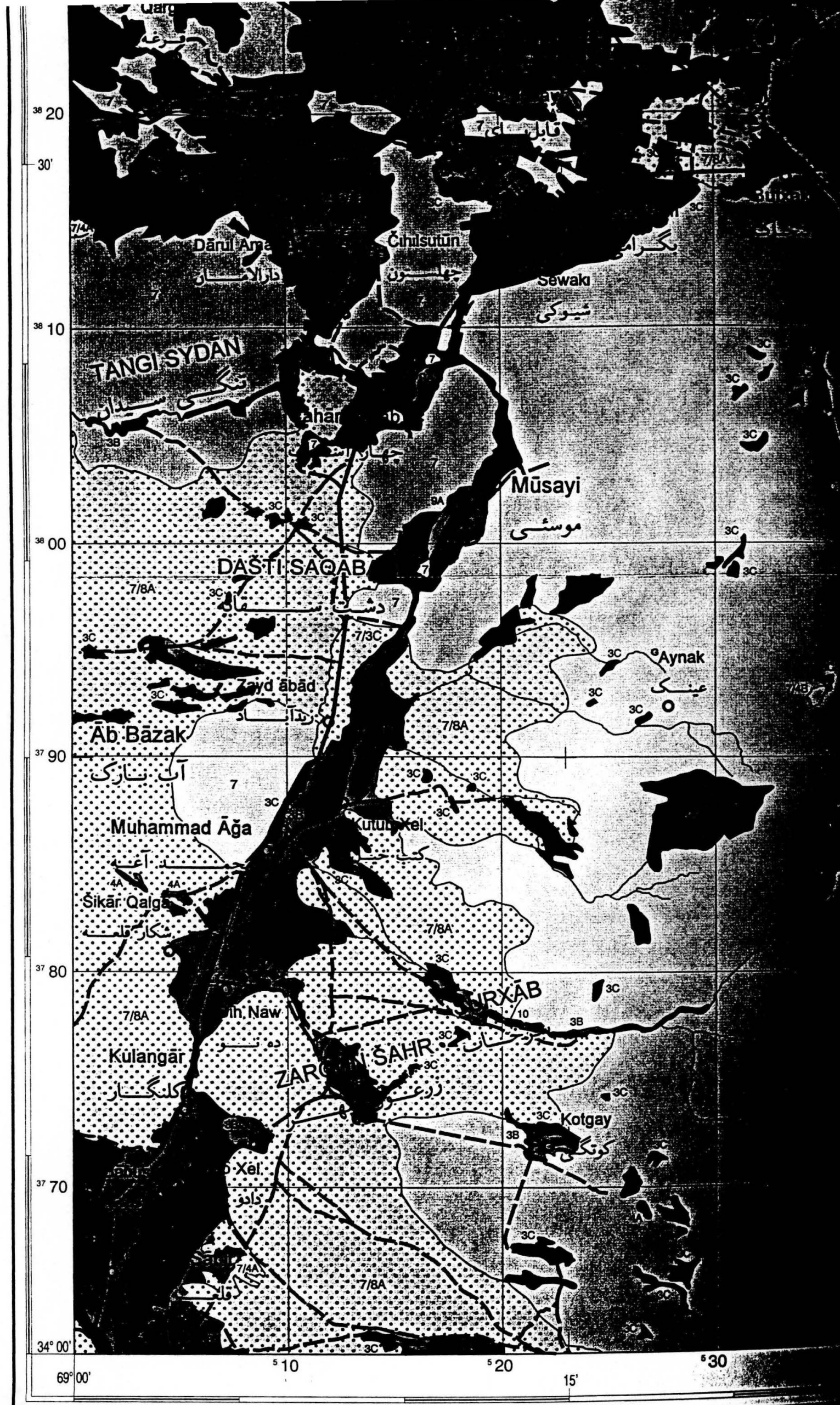

